\title{
Thinking about Entry of Firms: A Theoretical Discussion
}

\author{
Christian Garavaglia ${ }^{1}$ \\ ${ }^{1}$ DEMS, University of Milano-Bicocca, Milano, Italy \\ Correspondence: Christian Garavaglia, DEMS, University of Milano-Bicocca, Piazza dell'Ateneo Nuovo, 1, \\ Building U7, II floor-20126 Milano, Italy. Tel: 39-02-6448-5851. E-mail: christian.garavaglia@ unimib.it
}

Received: November 27, 2015

Accepted: December 31, 2015

Online Published: January 25, 2016

doi: 10.5539/ibr.v9n2p46

URL: http://dx.doi.org/10.5539/ibr.v9n2p46

\begin{abstract}
This paper analyses the factors that play a role in determining entry of new firms into markets from a theoretical point of view. We analyse the traditional interpretation of entry as a mechanism of re-equilibrating profits towards their long-run level. Then, we concentrate on other theoretical approaches, showing how the characteristics of technological innovation, the endowment of skills and competencies of the entrants, the role of information signals, the phases of the industry life cycle, the sociological concepts of legitimization and competition, and the psychological aspects might play fundamental roles in explaining new entry. The paper debates possible cross-fertilizations among theories: The discussion results in some fruitful intertwinements among the different relevant features about entry and spawns new collaborative and interdisciplinary research to create additional knowledge about entry. Insights about international entrepreneurship (IE) are also discussed.
\end{abstract}

Keywords: entry, international entrepreneurship, multidisciplinary, models

\section{Introduction}

This paper analyses the process of entry of firms into markets from a theoretical point of view. Entry is a common feature of all industries, and it represents a key aspect to be studied in order to understand industrial turbulence (Geroski, 1995; Caves, 1998). In this paper we consider entry as a new appearance of a producing firm in an industry in a country. Entry has increasingly been considered an international phenomenon: entry of firms into new international markets has gained more attention among scholars in the last decades (see Keupp \& Gassmann, 2009; Cumming et al., 2009). Competition between local incumbents and both local and foreign entering firms is the heart of the dynamics in the modern industries. Understanding entry of new firms directly leads to the understanding of entry of firms into new international markets.

The idea that entry and entrepreneurship are complex and multidimensional phenomena is not new (e.g. Gartner, 1985; 1988; Bruyat \& Julien, 2001; Ibrahim, 2004; Pittaway, 2005; Davidsson, 2005; Landström \& Lohrke, 2010). A single model and investigation would be too limited to assess such a complex issue. Different fields of study have been interested in examining the essence of entrepreneurial activities: Despite the potential richness that such a variegate mixture of disciplines brings, a major weakness is that in several cases researchers from one discipline tended to ignore important studies in other disciplines (Bull \& Willard, 1993). Therefore, many papers claim the adoption of a multidisciplinary perspective to study entrepreneurship and international entry and consider disciplinary diversity beneficial to researches (McDougall \& Oviatt, 2000; Oviatt \& McDougall, 2005; Zahra et al., 2005).

Many reviews in different disciplines have been written about entry, entrepreneurship and international entrepreneurship (IE) (see among others Casson, 1982; Gartner, 1985; Geroski 1995; Caves 1998; Coviello \& McAuley, 1999; Shane \& Venkataraman, 2000; Swedberg, 2000; McDougall \& Oviatt, 2000; Zahra \& George, 2002; Acs \& Audretsch, 2003; Coviello \& Jones, 2004; Ireland \& Webb, 2007). However, the development of the researches have been mainly focused on issues specific to their discipline's field.

We do not aim at developing a review of the reviews here: It would be a too much broad and loose task. On the contrary, the aim of this paper is to identify a selected literature which we believe to be relevant in order to investigate the determinants and conditions that characterise the process of entry of firms, and to propose a framework of analysis for better understanding entry. Combining different views and methodologies is required to make different features relevant, to provide a view of things that are not usually seen or that are seen in a different way (Carroll \& Hannan, 1995). Also, no single view reveals appropriate in the conceptual interpretation 
of internationalisation (Coviello \& McAuley, 1999). Therefore, the original contribution of this paper is not the proposal of a new model but the configuration of existing models in a different framework of study.

Our discourse does not pretend to be comprehensive; however, we claim that the analysis might be relevant for those scholars interested in studying entry. First of all, because we claim that studies about entry need disciplinary diversity to be comprehensive and beneficial (McDougall \& Oviatt, 2000; Coviello \& Jones, 2004; Oviatt \& McDougall, 2005; Zahra et al., 2005): Combining different views and methodologies is required to make different features relevant. Secondly, because we point out some results which we believe to be useful for the implementation of IE strategies and for IE researches. Our conclusions require studies on entry and IE to focus on 3 aspects: a) to deepen the analyses on the explanations which lead firms to consider the expected level of profits after entry larger than the entry cost: The role of capabilities is the key variable in these studies; b) to tailor the analyses on the specific features of the given industry under examination: an operational and effective study about entry and IE strategies need to be industry-specific; c) to explicitly give a crucial role to the dynamics of the context and analysis: Entry and international entry strategies should be different according to epoch of the evolution of the specific industry under consideration and management needs to monitor the disclosure of information and manage the uncertainty in order to identify and act upon profit opportunities in foreign market over the stages of the industry life cycle.

Some managerial considerations immediately follow, focussing in particular on the crucial role that dynamic capabilities have in implementing effective strategies about entry decisions and international entrepreneurial behaviours in heterogeneous dynamic contexts.

The paper is structured as follows: In the following section, we discuss some selected relevant theoretical approaches on entry. First, we analyze the traditional interpretation of entry as a mechanism of re-equilibrating profits towards their long-run level. Secondly, we present the psychological approach. Third, we present the industry life cycle model. Then, we concentrate on the characteristics of a technological innovation, the endowment of skills and competencies of the entrants, the role of information and its importance in determining the timing of entry, and the sociological concepts of legitimization and competition. A concluding discussion integrates and intertwine the relevant aspects which emerged about entry and IE. A section about managerial implications concludes the work.

\section{A "Round Table" among Theories about Entry}

This section analyses the point of view of different theoretical approaches in explaining and interpreting the entry process. Entry and IE are complex phenomena. The understanding of different theories is useful in order to study and investigate complex phenomena, that necessarily need more than a single lens to be deeply understood. Moreover, our approach is multidisciplinary: We investigate the relevant factors which explain entry according to different methodological perspectives. We claim that integrating various theoretical and methodological approaches from different disciplines could stimulate theoretical advancements in the knowledge about entry and entrepreneurship and encourage collaborations among researchers from different fields.

\subsection{Entry as a Profit-Driven Phenomenon}

According to the traditional theories, entry of new firms occurs every time there is a level of profits in excess of long-run equilibrium in the market. Therefore, newcomers are seen to exist purely as a response to the existence of high profits, and the process of entry is considered a re-equilibrating function of the market: New firms, stimulated by the existence of extra-profits, enter the industry and, in doing so, they push profits to their long-run competitive level, where no more entry occurs. This approach is summarized by the typical orthodox model of entry:

$$
E_{j t}=\gamma\left(\Pi_{j t}^{e}-b_{j}\right)+\varepsilon_{j t}
$$

where $E_{j t}$ represents entry at time $t$ in the $j$-th industry, $\gamma$ represents the speed of adjustment of entry to the existence of extra profits, $\Pi_{j t}^{e}$ is the expected level of profits after entry has occurred, $b_{j}$ is the level of the so-called "limit profits", that is, the long-run level of profits of the industry $j$ protected by entry barriers without attracting entry. Clearly, whenever $\Pi_{j t}^{e}>b_{j}$, there is a positive flow of entrants, $E_{j t}>0$.

There are many empirical results about the role of profits in stimulating new entry (Khemani \& Shapiro, 1986; Kessides, 1990; Barbosa, 2003; Orr, 1974; Duetsch, 1984). In this context, one observation does seem to be generally accepted: In the debate among the economists about the role of the presence of high profits in inducing new entry into the market, it is suggested that if there is a positive effect of high profits on entry, entry responds 
only slowly. There is a time lag in the entry decision as a response to the existence of high profits (Schwartz, 1986; Ghemawat, 1987; Barbosa, 2003).

The exploitation of profit opportunities is also considered the driving force of entry in a foreign market in IE studies. In this context, IE has increased in the last decades because more efficient transportation and communication technologies enabled the internationalisation of entrepreneurial opportunities, by increasing the speed of the diffusion of information and knowledge about opportunities, and reducing the costs of the movement of resources among countries (Oviatt \& McDougall, 2005). Also, the motivating force to take pre-emptive advantage of an opportunity in a foreign country, because of the risk that a local firms would respond quickly and prevent other firms entry, influences the internationalisation speed of new entry.

The important contribution of this approach relates to the explanation of the existence of some kind of barriers to entry which affect the entry process, represented by the term $b_{j}$ that indicates the level of profits sustainable in the long-run at which entry is absent. Differences of profit rates among industries and countries need to be explained by some restrictions to entry (Bain, 1956): It is exactly the existence of entry barriers (i.e. $b_{j}$ ) that prevents potential entrants from exploiting profitable market opportunities and allows established firms to obtain super-profits. Basically, the nature of entry barriers is related to the combination of two conditions: the structure of the industry and the incumbents' responses to potential entry. While it is not the purpose of this paper to explore the wide literature about entry barriers, it suffices to say here that in order to understand the process of entry we need to study and consider explicitly the structural conditions of the industry and also the strategic entry barriers (that is to say strategic behaviours of the incumbent firms put forth in order to keep the potential entrants out of the market). With the proliferation of game theory in economics, the strategic interaction among potential entrants and incumbent firms received much attention. Here, the concept of strategic barriers to entry is crucial. The game-theoretic approach presents the same logic as the traditional view.

If we consider the entry decision as a complex phenomenon, then it is natural to claim that this approach seems to be too stylised and too much oriented towards another phenomenon-i.e. entry barriers-to explain entry.

\subsection{A Psychological Investigation}

Economic models typically assume that economic agents behave rationally. Usually in mainstream economics the hypothesis of perfect foresight and full rationality in the decision processes of consumers and firms takes the form of maximising behaviour of a certain objective function, like utility or profits. This assumption represents the skeleton of traditional thinking. Other models have been proposed in the economic literature and other assumptions have been made about the economic behaviour, for example, bounded rationality, satisficing behaviour, routinized decision rules and herd behaviours (Simon, 1982; Nelson \& Winter, 1982; Banerjee, 1992; Bikhchandani et al., 1992). Moreover, the empirical evidence shows that economic agents depart from the perfect rationality assumption of the rational models and represent informational data in an unreliable and incoherent way. An inspection of the use of alternative psychological assumptions in economic models is useful also in interpreting the determinants and the process of entry of new firms as well as the internationalisation of firms (Zahra et al., 2005).

A cognitive and psychological investigation of economic behaviour reveals the presence of biases about one's own abilities and competencies, in terms of technological skills or competitive competencies in general (Cooper et al., 1988). The decision of entry undertaken by entrepreneurs can also be considered in the perspective of these limitations. Also, the cognitive perspective about IE considers why some firms are able to bear better with uncertainty in international environments and exploit international opportunities (Butler et al., 2010). The basic explanation of the pattern of entry refers to the concept of "over-confidence" or "over-optimism". The entry phenomenon, according to this approach is a "knowledge-centred story" (Dosi \& Lovallo, 1997), in the sense that when entrepreneurs think they perceive the existence of opportunities in the industry, they decide to enter the market because of the owned competencies that might make the opportunity profitable. The thought of holding the necessary competencies in order to become profitable in the market competitive arena is related to the ability to absorb uncertainty and to the knowledge of the firm. This is particularly relevant in the international context, as claimed by Butler et al. (2010) because international entrepreneurship incorporates even more uncertainty than domestic entrepreneurship.

Many experiments show that people think themselves to be more able in understanding complex situations than they really are, and usually disregard others' bad past experiences, thinking they are competent enough to control complicated circumstances. The excess of unsuccessful entry, in fact, bears witness to the existence of some distortions in the perception of the opportunity of such an entry choice: Otherwise, firms would take into account the high probability of failure and try their luck less frequently. Entry decisions, however, are not merely 
mistakes originating from wrong forecasts carried out by "brave agents": The hypothesis of risk-aversion still holds. In this sense, over-confidence explains the co-existence of the risk-adverse attitude of agents with the personal belief in succeeding where most other agents fail.

Replicating an industrial environment with an experimental model, Dosi and Lovallo (1997) investigate the presence of psychological factors in influencing the entry decision. The participants to the experiment were given information about the market, such that they were able to make predictions about the opportunities of entry. Subsequently, participants were asked to predict the number of entrants and their entry decision. The experiment was designed in order to create different situations: A random-ranked condition in which the participants were given an order in which to make the entry decision, and a skill-based condition in which the participants were assigned a quiz and the decision rank was defined with respect to the correct answers given by each subject. The difference in the number of entrants in the two situations is the most interesting finding of the experiment, which could signal the presence of more confidence about one's own abilities in the skill-ranked situation. The results of the experiment show that there was excess entry in the skill-based setting in every experiment that the authors ran. Given that the participants made accurate forecasts on the number of entrants, the cause of this phenomenon does not appear related to the so-called "blind spots", but more likely it is the consequence of an over-confident attitude of the subjects in the skill-based condition; they seemed to behave as if they were thinking "I realize that on average people are going to lose money in this market, but I'm not. I'm in!" (Dosi \& Lovallo, 1997). Related to this, a second result from the experiment shows the existence of a "reference-group neglect" phenomenon, that is the presence of undervaluation of the abilities of other subjects in the group one is competing with. The puzzling result is that " $[\ldots]$ in a sequential-entry environment, people are making a decision to enter knowing with probability one that the value of the game to the player as a group is already negative!" (Dosi \& Lovallo, 1997).

The psychological investigations are useful to study entry because they highlight that it is the perception about own competencies that people think to hold which really drives the evaluation of the expected profit, and then finally leads to the decision to enter or not. Some entrepreneurs may not hold crucial skills and competencies, however they decide to enter into the market. The drawback of these studies is that they are usually decontextualized, disregarding if over-confident behaviours vary depending on the specific context (technology, epoch, national vs foreign market) under study.

\subsection{The Industry Life-Cycle Theory}

Extra-profits opportunities, technological conditions, the pattern of the entry process and IE are determined by the stage of the development of the industry. At the beginning of the evolution, after the introduction of the product, many industrial sectors experienced rapid flows of entry, which after a certain period started to level off, and then decline when the industry went through its stabilization phase (Gort \& Klepper, 1982; Klepper \& Graddy, 1990; Klepper \& Miller, 1995; Klepper, 1996, 1997; Utterback \& Suarez, 1993). Many industries' evolution follows this particular path. Industries such as television, automobiles, tires, and radio, illustrate how new firms comes in waves and usually peaks early in the development of the market, and entry by foreign firms comes from large enterprises that gradually export and establish subsidiaries, exploiting economies of scale and cost-advantages in the growth and maturity phases of the industry life cycle (Vernon, 1966).

The industry life cycle models (Jovanovic \& MacDonald, 1994; Klepper, 1996) formally explain these phenomena. This approach dates back to the seminal works by Utterback and Abernathy (1975), Abernathy and Utterback (1978) on the product life cycle. The product life cycle theory explains the evolution of products from birth through maturity: Typically, at the beginning, different variants of the product or design are available in the market, and there is high uncertainty and little consensus about the performance and the relevant characteristics of the products. As development proceeds, through a growth phase up to a maturity phase, specific product designs become dominant (in some cases a single dominant design emerges), the product is more standardized and the consumers' needs become clear. In accordance with this, the industry's characteristics also evolve following different phases. The early phase is characterized by a radical innovation that gives birth to the industry: Total output volume is very low, product innovations are frequent, market shares continuously change and there are low entry barriers. At this stage, many new entrants enter the market, and the number of firms grows rapidly. In the growth phase of the industry, output considerably grows, the number of versions of the product decline and more investment is devoted to process innovation. Barriers to entry become significant, entry rates slow down and exit typically leads to a shakeout in the number of producers. In the maturity stage, output growth slows, market shares are stable, the industry is concentrated and the entry barriers are high. Innovations tend to be fewer, and mainly concern the production process. In this context, the process of entry levels off, and newcomers find it very difficult to compete with the incumbents. 
Klepper (1996) proposes an interesting explanation of the industry life cycle without referring to the concept of dominant design. The model finds the firms' innovative capabilities and the role of size in influencing R\&D investment decisions to be the key elements that shape the evolution of the market structure. Two plausible entry paths emerge: In the first, the number of entrants reaches its maximum at the start of the industry and then it declines (as happened in the television industry in USA), while according to the second path, the number of entrants firstly rises over time and then it decays (as in the automobile and the tyre industries in USA). In both situations, however, the number of new entrants becomes small (Figure 1).

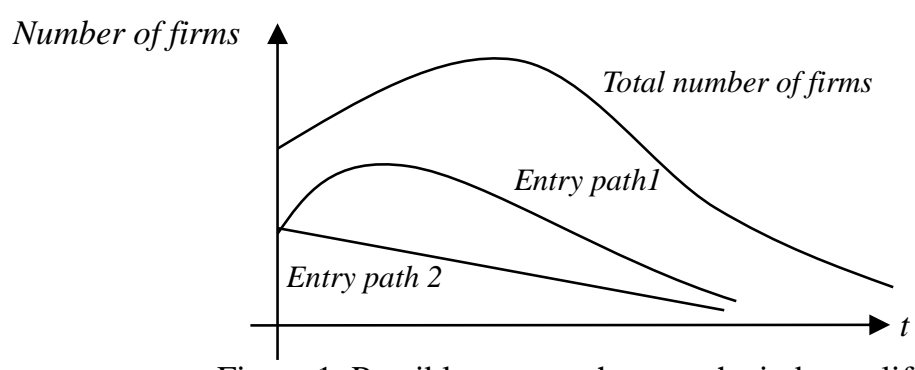

Figure 1. Possible entry paths over the industry life cycle

Intuitively, the driving force of the model is given by the dependence of the returns of process R\&D on firm size: Bigger firms have more incentive to invest in process $R \& D$ because they would benefit from a cost reduction on a larger output (for a formal description of the model see Appendix A). This leads the less innovative and efficient firms to exit the market because the price falls over time as long as output expands. This means that later entrants need to be relatively more efficient in product innovation in order to find entry profitable. However, at some point in time the entry process stops, given that the potential entrants have a larger and larger cumulated disadvantage with respect to incumbent firms.

What does this model tell us about entry? First of all, the basic determinant of the process of entry, given by the profitability of the entry decision $\left(\Pi_{\mathrm{it}}^{\mathrm{e}}{ }^{*}>0\right.$, in Appendix A), is an explicit function of the innovative competencies ( $s_{i}$ in Appendix A) of the firm. Firms are heterogeneous and consequently they respond differently to the market opportunities and stimuli: it follows that the model is able to predict that entrants are different among them, and that entry and exit are simultaneous. Moreover, entry and $\Pi_{\text {it }}^{\mathrm{e}}$ depend on R\&D investments. Product innovations are typically introduced by newcomers, while process innovation is led by incumbent firms. The resulting rate of innovation predicted by the model, including both process and product, is represented in Figure 2. Finally, the process of entry is seen as a dynamic phenomenon, that follows different phases in accordance with the evolution of the industry. In each of these stages different factors are relevant in explaining entry, and the phenomenon of entry is seen and explained in connection with other structural characteristics of the industry, in particular, product and process innovation.

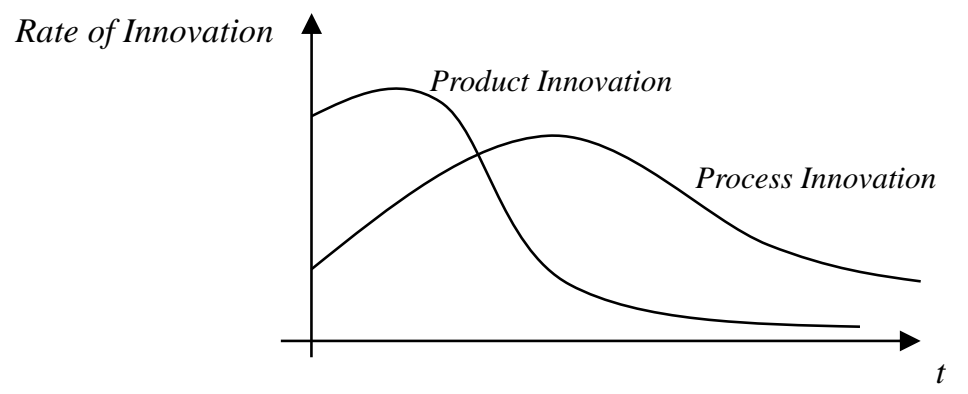

Figure 2. Product and process innovation over the industry life cycle

In this story, IE typically follows a stage evolution. The well-known Uppsala model describe the process of entry of firms in new foreign markets as a sequence of international activities, beginning with occasional exports, through regular exports, to the development of an international division and the establishment of a fully integrated enterprise (Oviatt \& MacDougall, 1994). Exploiting economies of scale in the home country, firms start to internationalize by exporting in foreign markets. International competition becomes tougher and 
low-wage countries' firms exploit low cost strategies in an international context. Subsequently, firms gradually acquire knowledge about foreign markets and increase their commitment to these markets by establishing a sales subsidiary or beginning production (Johanson \& Vahlne, 1977).

The staged development of firm internationalization has been criticized. Many firms skipped stages with unexpected speed in their development of foreign divisions, and many other firms born global by seeking to exploit their competitive advantage in multiple countries from inception (Oviatt \& MacDougall, 1994). This phenomenon seems to be particularly related to high-tech firms, as well as to changing economic, technological, social conditions that increase the speed of information, communication and homogenization of markets. Again, the study of technological change and innovations, the spread of information and knowledge firm-specific traits, become crucial to add richness to our framework about entry and IE. We turn to these aspects in the following sections.

\subsection{Technological Regimes}

Self-perception of technological competencies influence entry decisions, as mentioned in Section "A Psychological Investigation". Relatedly, the technological features of a given market are crucial in determining entry choices. Since the last century, in "The Theory of Economic Development" (1934) Joseph Schumpeter focused his attention on the role played by technological discontinuities and entrant firms in shaping the evolutionary dynamics of industries. The "innovator entrepreneurs" play a crucial role in the dynamic process of the capitalist economies: motivated by the expected profits associated with the introduction of the new technology and, not less importantly, by their creative spirits and by their "personality", they start up new firms and destabilize the market, displacing the existing firms.

Following this view, then, it is possible to understand the economic process of industrial change as a continuum of periods of dominance of a certain technology and its related incumbent firms, followed by a new technological breakthrough and the entry of new firms displacing the old ones. According to this version of events, the main determinant of the process of entry must be found in the opportunities opened up by the technological innovations and by the innovative capabilities of the new entrants.

The concept of technological regimes (Nelson \& Winter, 1982) emphasises the role of the technological attributes of an industrial environment. Referring to the works of Schumpeter, "The Theory of Economic Development" (1934) and "Capitalism, Socialism and Democracy" (1950), it is possible to distinguish two different patterns of economic development. The first, related to the young Schumpeter's view, describes the process of economic change as a continuous unveiling of new products and innovations, displacing the existing ones, by entrepreneurs associated with new firms. This is the famous notion of "creative destruction", in which "[...] new combinations are, as a rule, embodied in new firms which generally do not arise out of the old ones but start producing beside them" (Schumpeter, 1934). Winter (1984) defined this view as the "entrepreneurial regime", contra-posed to the "routinized regime". In the former, the innovative activity is carried out by newcomers, who drive the existing firms into decline (Winter, 1984), while in the latter the innovative conditions are favourable to established firms as the major source of innovation, as expressed by Schumpeter in "Capitalism, Socialism and Democracy" (1950). In this latter case, then, established foreign firms might take advantage of thier experience in discovering, enacting and exploiting opportunities that cross national borders, thus internationalising their action. The ability of exploiting these opportunities depends both on the characteristics of the knowledge and experience of the firm and on the characteristics of the technological regime.

Are technological regimes country-specific or technology-specific? According to this line of research, then, the determinants and causes of the process of entry of new firms need to be studied and understood with regard to the specific technological environment under examination. Technological regimes are usually defined by the combination of four different factors (Malerba \& Orsenigo, 1995), i.e. technological opportunities, appropriability conditions, cumulativeness of technical advances and dimensions of knowledge base. The combination of these factors gives rise to the definition of two different patterns of innovative activities, named "Schumpeter Mark I" or "widening", and "Schumpeter Mark II" or "deepening". Similarly to the analysis of Winter (1984), these patterns are associated with the role played in the innovative activities by the new innovators and by the incumbent firms, respectively.

Linked to the notion of technological regimes is the work of Audretsch (1995). Audretsch proposes, and empirically tests, two different models of industry evolution. On the one hand, the model of "the conical revolving door" shows that there is a flow of new entrants which after some periods exit the market, leaving the incumbents in relatively the same condition as before the entry process occurred. On the other hand, there is the model concerned with the "metaphor of the forest", in which the new entrants displace the established firms and 
force them to exit the market. These two models are strictly related to the concept of technological regimes: the first recalls the "Schumpeter Mark II" regime, while the "metaphor of the forest" is closer to "Schumpeter Mark I". Industries such as electronics computing equipment and process control instruments, in which small firms have an innovative advantage over large firms, conform to the metaphor of the forest. In other sectors, such as pharmaceutical products and aircraft, large firms generate most of the innovative activity, thus being consistent with the model of the revolving door (Audretsch, 2002).

What we learn from the technological regimes approach is that we cannot generalise the understanding of the process of entry, disregarding the technological features of the industry: Some technological conditions favour entry more than others. The introduction of a new technology represents new opportunities for existing firms as well as for newcomers, for local firms as well as foreign ones. Entry is explained as a vehicle to exploit the market opportunities opened up by the technological evolution of the industry, which brings new knowledge and capabilities. According to this view, the process of entry is, then, competence-driven. The innovative expertise and knowledge of the entrant firms, together with the technological conditions, represent the relevant aspects that we have to study in order to understand the meanings and the determinants of entry.

This conclusion is robust across countries; that is to say, entrepreneurial activities generated by technological opportunities are technology-specific and not country-specific (Malerba \& Orsenigo, 1996).

\subsection{Technological Change and Firms' Competencies}

The explanation given by the competence-enhancing and competence-destroying approach is strictly linked and complementary to the technological regime theory. The focus of the analysis is again on the role of technology. In addition, here, a distinction between which type of technological change occurs and the effects on the competencies of firms are explicitly considered.

According to this approach, firms are repositories of knowledge and specific competencies, technological changes affect the validity of competencies associated with the technology, and as a consequence the process of entry of new firms is explained in terms of the type of the technological change. Distinguishing between the concepts of competence enhancement and competence destruction is, then, of particular interest for the study of the emergence of new firms in the industry and of the evolution of market structures.

Competence-destroying discontinuity is associated with new knowledge and capabilities deriving from the utilisation of new technology, which differ from the expertise previously developed by the incumbents, and from the know-how linked to existing products and production processes. On the other hand, competence-enhancing technological change further improves upon the existing technology, building on the experience, skills and competencies that have already been accumulated by the incumbent firms over time.

In the former case, the effect on the market structure is disruptive. New firms enter the market embodying the new knowledge and technological expertise. They are revealed to be more effective and faster in the introduction of the new technology, while the incumbent firms demonstrate a sort of lock-in into the old procedures and existing technology. The existing technology is then rendered obsolete by the entrance of the new firms. The result is the emergence and dominance of a new population of entrants, that displace the existing firms from the market. This does not occur in a situation of competence-enhancing technical change, where incumbents can rely on their experience and accumulated knowledge base, which turn out to be necessary in the process of exploiting the new technology and competencies. Tushman and Anderson (1986) and Anderson and Tushman (1990) examine the cases of different industries (cement, container glass, flat glass and mini-computer industries) in which competence-destroying and competence-enhancing technological discontinuities shaped the evolution of the market structure.

In presence of changes in the technological knowledge base, new firms may want to explore their knowledge development across many countries. These new born-global firms internationalise from inception being faster and more effective in the introduction of the new technology, with respect to the incumbents which are locked into old procedures and routines (Autio et al., 2000; Zahra et al., 2000): their organizational capabilities and innovativeness support their superior performance in various countries (Knight \& Cavusgil, 2004). More generally, many researches emphasised how IE activities are positively related to industries where rapid technological change is common (McDougall et al., 2003). International entry focuses on the provision of innovative, differentiated, high quality products and services, by using unique technological knowledge, thus gaining a competitive advantage over domestic firms (Oviatt \& McDougall, 1994, 1995; McDougall et al., 2003).

What do we learn from this approach? Basically, we recognize the need to study entry by looking at the type of 
technological change and more precisely at its effects on the firms' competencies. According to this view, we can say that the process of entry is competence-and knowledge-driven: Entry and IE occur because of their ability to create, bring and explore new knowledge that generate profit opportunities. We conclude now that the type of technological change and the effects on firms' knowledge is central in explaining which firms enter, when and where. Many empirical works show how entry and survival are positively correlated with the endowment of new entrant's skills and knowledge. Barbosa (2003) finds that human capital variables have a stronger effect on entry than profit ones. Brüderl et al. (1992) show that the survival probability of entrants seems to be positively related to the education of the founding entrepreneurs, and Mata (1996) shows that entrepreneurs with higher schooling start with initial larger firms. Also in IE, researches show how the entrepreneurial team experience (McDougall et al., 2003) and perception of capabilities (Sommer, 2010) influence the propensity and intention to enter international new markets. Zahra et al. (2000) show that international performance of firms is related to firm's knowledge gained through technological learning. The characteristics of the knowledge base of the firms' decision makers and entrepreneurs are then crucial to understand the decision of entry of firms into international markets and the fate of entrant firms. In this respect, Mejri and Umemoto (2010) claim for a knowledge-based model of firm internationalisation, supporting the idea that market knowledge, experiential knowledge, network knowledge, cultural knowledge and entrepreneurial knowledge explain the decision of firms to become international, their performance and strategy of entry.

\subsection{The Role of Information and Uncertainty}

The decision by potential entrants to enter a new market requires, first of all, the identification of the profit opportunities in this market. Information can be explicitly considered to explain entry into an industry and IE. If we realistically assume that information is not perfectly diffused among the economic agents, then it becomes obvious that the entry decisions also depend on the level of information held by a firm.

The role of information and uncertainty to explain entry has been analysed in a theoretical model proposed by Horvath et al. (2001). Looking at the life cycle pattern of some industrial sectors, like beer brewing, automobile and tyre industries, it is surprising to notice how the industrial evolution is characterised by a period of infrequent entry, followed by a wave of mass-entry and a subsequent shakeout. The model explains the shakeout by considering that empirical findings show a clear stability of the hazard function over time. This implies that a shakeout can be explained as the natural consequence of a previous period of mass-entry. What we need to explain, then, is the phenomenon of mass-entry. The crucial assumption of the model is that there is uncertainty about future profitability at the moment of undertaking the entry decision. It is by observing the post-entry results of other firms that potential entrants untangle their uncertainty about future profitability. Thus, a mechanism of informational cascade can explain the mass-entry phenomenon: firms that initially may be pessimistic about the future, due to the fact that entry may reveal to be unprofitable, can resolve their uncertainty and may decide to enter the market by observing the experience and the performance of the established firms. The conclusion is that "as more firms enter the market, more information gets released to potential entrants by their operations, speeding up the resolution of uncertainty and triggering additional entry whenever the likelihood of a good market increases" (Horvath et al., 2001).

This process explains the entry decision of new firms in terms of the informational uncertainty about the future viability of the industry: The more informative the signals from the incumbent performance are, the more information will be revealed and consequently the more likely a mass-entry phenomenon is to occur. Along this line, Butler et al. (2010) discuss the ability of entrepreneurs to absorb uncertainty associated with exploiting an opportunity and the ability of bear uncertainty as determinants for IE. These abilities play a key role for the achievement of a competitive advantage of the international entrepreneur. In this context, the ability of managing uncertainty of the firm relates to the alertness to respond to the signals coming from the observation of the post-entry results of other firms untangling uncertainty about opportunity and profitability.

In a formal representation of the model, the idea of uncertainty about future profitability is represented by assuming that not all the firms in the industry certainly obtain an order for their product every period. The unknown probability of receiving an order is $q$ : A higher value of $q$ implies, then, higher expected profits. Firms at time 0 hold initial beliefs about $q$ summarised by the probability density function $g_{0}(q)$ : These beliefs are updated according to the number of orders relative to the number of incumbents. Potential entrants learn the true value of $q$ by observing the active firms in the market, forming their expectations over the value of being in the market in the subsequent period. The model is solved numerically, and the equilibrium number of incumbents, $N$, is determined as a function of the value of $q$. In the simple case in which the prior distribution of $q$ is characterised only by two values, $q_{l}$ and $q_{h}$, with the prior $\operatorname{Pr}\left\{q=q_{l}\right\}=\alpha$, the results of the model are determined by the distance $d$ : 


$$
d \equiv q_{h}-q_{l}
$$

which indicates the informational content of the signal. A higher value of $d$ means that the agents' beliefs are updated faster. In fact, the extreme case in which $q_{h}=q_{l}$, that is $d=0$, means that a given realisation for entry is as likely under each value of $q$. On the other hand, when $d$ is high, we have diverse evaluations from the same realisation. As a consequence, the simulation results show the importance of $d$ in driving the evolution of the industry: When $d$ is high, the process of entry is fast, while in the case of low $d$, it is smoother. Moreover, if we allow the prior distribution to be more diffuse (for example, a continuous function), then, new information coming from the observable firms does not lead to a large updating of the beliefs. As a consequence, the shape of the pattern of entry becomes more diffuse (Note 1), and eventually it might take a different form. The simulation results, as reported in Figure 3, illustrate how a concave shape might emerge.

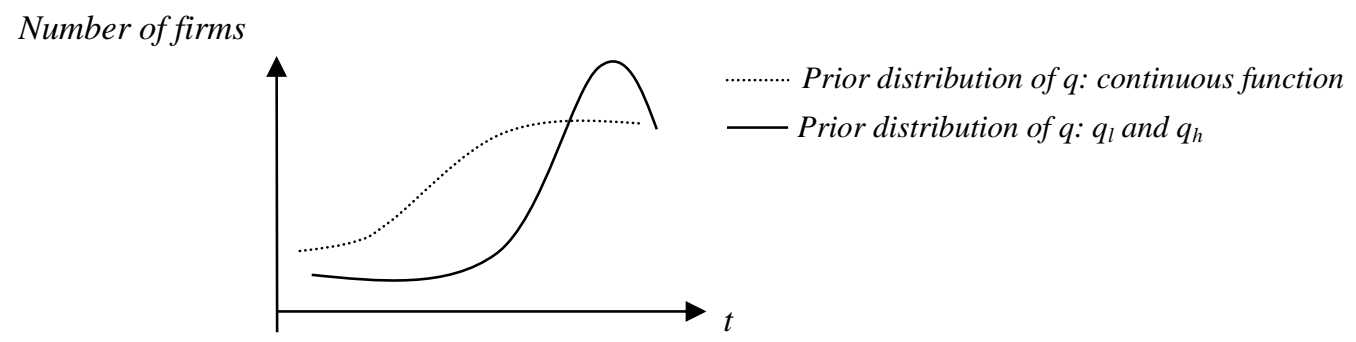

Figure 3. Paths of entry

This model is useful for investigating entry and IE because it reveals how the informational content of the signals related to other firms' experiences may influence the waves of subsequent entry. If other experiences are highly informative then entry may stimulate new entry. The diffusion of information matters in affecting entry and IE.

\subsection{Organizational Ecology: The Legitimization Process of a New Organizational Form}

The sociological approach of the "Organizational Ecology" theories explain the entry process of firms from the point of view of the firm population more than on the single firm's decision (Hannan \& Freeman, 1984). Firm populations' (or more broadly organization populations') long-run evolution is examined in terms of vital rates: Birth, survival and mortality rates. Two sociological forces drive the evolution of the populations: The process of legitimization and the process of diffuse competition, and the key variable of the model is given by the population density, i.e. the number, $N$, of organizations in the population. Let us focus on the founding rate of new organizations and its relationship with the two driving forces.

The process of legitimisation, $L(t)$, indicates the taken-for-granted attitude in considering a given organisational form. According to the legitimisation, a particular organisational form follows a time process during which it becomes considered more and more the natural way of doing certain things (Carroll, 1997). At the very first manifestation, a new organisational forms lacks legitimisation, suffering the "liability of newness" effect: There might be general hostile behaviour from suppliers, customers and institutional authorities; workers might be hard to find; suppliers must be properly well-informed about the needs; customers need to be persuaded; usually capital resources are limited because of the risks and the reluctance of financing institutions associated with something new. As the organisational form diffuses, its legitimacy rises. The effect of this process, however, is decreasing: The legitimization effect added by the additional organization is positive, but it increases with a population's density at a decreasing rate. In other words, the effect is stronger when there are few organizations in the populations and it reaches a ceiling when $N$ is high.

The process of competition, $C(t)$, indicates the level of competition among firms when they depend on the same set of resources. The resources are finite and consequently the competition becomes more and more fierce when the number of the same type of organization proliferate. This means that the effect of diffuse competition increases with the increase in $N$ at an increasing rate.

The founding rate of new firms, $\lambda(t)$, is positively influenced by the legitimization effect and negatively by competition:

$$
\lambda(t)=a(t) \frac{L(t)}{C(t)}
$$


The expression (3) of the founding rate typically exhibits a non-monotonic relationship with the population's density $N$. The model also specify the relationship between these forces and the mortality rate $\mu(t)$. This gives rise again to a non-monotonic pattern: initially the mortality rate falls as a function of $N$, and secondly it rises, generating a U-shaped path. Graphically we can depict $\lambda(t)$ and $\mu(t)$ as in Figure 4.

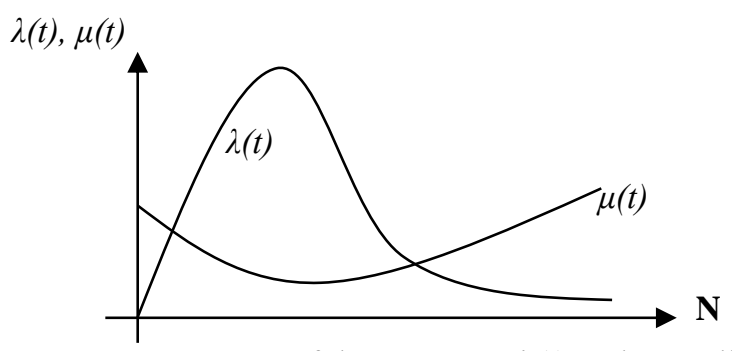

Figure 4 . The patterns of the entry rate $\lambda(t)$ and mortality rate $\mu(t)$

For our purposes, it is important to emphasise the determinants of the dynamics of entry, that is to say the inverted U-shaped pattern of the founding rate in the model. At the beginning of the organisational population's evolution, the legitimization effect prevails over the competition, while as $N$ increases at later stages, competition predominates. While the legitimization effect is rising, the given organisational form gradually loses its character of novelty and becomes more attractive for entrepreneurs. Opportunities associated to this organisational form open up. Moreover, "[...] organizations founded during periods of increasing legitimation also find it easier to attract capital, suppliers, customers and employees. They also face fewer institutional obstacles" (Carroll, 1997). As a consequence, the model predicts increasing founding rates and declining mortality rates. But, with the subsequent increase in the number of organizations, the process of competition strengthens, while the legitimization effect increases little or none. These processes lead more and more to a reluctance in entrepreneurs to starting up new firms and accordingly the entry rate falls during this period, while existing firms find the going tougher, leading to higher rates of exit (Carroll, 1997).

This model is useful for interpreting IE. There is a legitimization effect also in IE: Liability of newness exerts a critical negative effect over international new entrants. A more hostile behaviour from customers and institutional authorities is particularly important when costs related to product and service failure or non-performance are relevant. Burgel and Murray (2000) call this difficulty "liability of alienness", Zaheer (1995) "liability of foreignness", Johanson and Vahlne (2009) "liability of outsidership". In this situation, the effect of the legitimization process of IE induces more other firms to operate internationally: As the number of international new ventures increases, then, we expect that the "liability of alienness" effect decreases.

With regard to competition we emphasise two effects on IE. On the one hand, the stronger the process of competition in a foreign market, the lower profit opportunities and consequently the lower the attractiveness to internationalise in this market. The more viable strategy to internationally enter becomes, again, the innovative, knowledge based, technological competitive advantage of the firm. On the other hand, the stronger the process of competition in the domestic market, the higher the incentive to expand internationally in order to increase sales volumes (McDougall et al., 2003). It comes out a picture in which, after a period of local development and legitimisation, firms tend to enter foreign markets to offset local competition. Only the more innovative firms might expand internationally since the beginning facing the international legitimization constraint and international competition by exploiting their innovative competitive advantage.

In conclusion, the organisational ecology approach is important in emphasising the presence of sociological forces in driving the population's evolution and the pattern of entry. The legitimization effect plays a crucial role in determining the viability of a given organisational form and its diffusion over time. The difficulties associated with the novelty of the beginning are shortly overcome, but more organizations imply a fiercer competition such that entry becomes steadily less attractive.

\subsection{The Resource Partitioning Model}

Many industries across countries experienced a rapid surge in the number of firms during the late stage (maturity) of their evolution: For example, the brewing industry, telephone companies, winemakers, the newspaper industry in the U.S. (Carroll, 1985; Swaminathan, 1995; Barnett, 1997; Carroll \& Swaminathan, 1992, 2000), the auditing firms in the Netherlands (Boone et al., 2000), the early American feature film industry (Mezias \& Mezias, 2000), 
the Italian brewing industry (Garavaglia, 2009). Both the organisational model of legitimization and competition and the industry life cycle theories are not able to explain such a phenomenon. Usually mature industries that exhibit high concentration rates are also characterised by strong entry barriers, such that it is not common to observe an increase in the number of entrants. The resource-partitioning argument helps to elucidate this issue.

The resource-partitioning model makes a distinction between "generalist" and "specialist" organizations' evolution inside the population, referring to the concept of "strategic groups" (Carroll \& Swaminathan, 1992; Caves \& Porter, 1977). When industry's concentration is high, there creates more "room" in terms of resources for new organizations. These organizations are typically small and assume a different organizational form from the prevalent one in the industry. The model explains how with the increasing concentration ratio, big generalist producers leave some resource space free for small specialist producers. Besides the typical standardized product of the generalist organizations, then, small specialist firms exploit the opportunities for typically more specialized products.

The two key concepts in this model are economies of scale and the resource space. The first mechanism explains the decline in the number of generalist organizations and a consequent rise in the concentration ratio, that in its turn increases the opportunities for specialist organizations. As a result, there is a flow of new firms entering the industry and the number of organizations in the population rises. The explanation of the resource space left to specialist organizations when the concentration level is high is given graphically in Figure 5 (Carroll, 1985). Let us depict a market representing the total amount of resources available to the organizations as a square, and let us represent the resources obtained by a given generalist organization as a circle (Note 2). The left area in the figure represents the available resources. Generalist organizations aim at the centre of the market (Note 3), and they slightly differentiate themselves to attract more and different consumers: This is represented by the overlapping circles in Figure 5, where the common area corresponds to those consumers who purchase the product (or service) of all the generalist organizations (Note 4). In Figure 5, two possible market configurations are reported. In market $\mathrm{A}$, there are three generalist producers, so we refer to this situation as an unconcentrated market. Meanwhile, market B is highly concentrated: In this case, typically, the organization is larger than in the less concentrated case, but the total market share is smaller. When economies of scale lead to a highly concentrated situation, for simplicity suppose only one firm, keeping the dimension of the market (i.e. the square) constant, it is possible to recognise that the "free area" representing the consumer resources that can be drawn on for sustenance without engaging in competition with generalists is larger than in the less concentrated market (Figure 5). This means that more small pockets of resources are left for smaller specialist organizations when the market is highly concentrated.
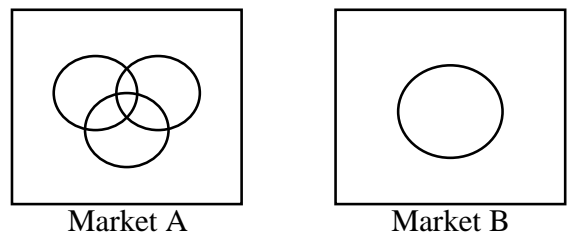

Figure 5. Resource space in an unconcentrated market (A) and in a highly concentrated one (B)

Interestingly, if we consider the two axes that constitute the market resource space as taste descriptors then an increase in the number of dimensions, $\underline{\mathrm{n}}$, of the Euclidean space stands for an elaboration in the customers' demand, which becomes more diversified and sophisticated. It can be proved that as the number of dimensions $\underline{n}$ increases, the resource utilization by generalist producers decreases, leaving then more unexploited resources to specialist firms (see Péli \& Nooteboom, 1999). If we define "packing density" as the portion of the total volume occupied by the hyperspheres (which represent producers) (Note 5), we can report a downward relationship between the number of dimensions $\underline{n}$ and the packing density, as in Figure 6.

It can be shown that the number of neighbouring spheres that touch a given sphere (the "kissing number") and, allowing spheres to overlap, the "covering thickness", which measures overlaps among spheres, exponentially increase with the number of dimensions $\underline{\mathrm{n}}$. This means that the greater the increase in the resource space dimensionality, the fiercer the competition among generalist organizations, and consequently the occupation of the remaining resource space becomes progressively more unfavourable for generalists, leaving room to specialist producers. 


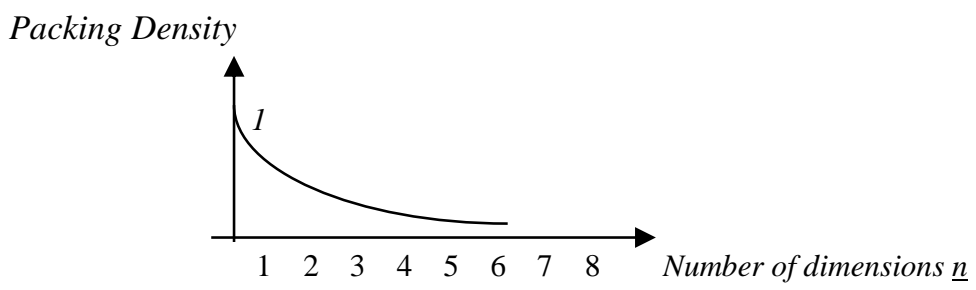

Figure 6 . The number of dimensions $\underline{\mathrm{n}}$ of the resource space and the packing density

The main relevant features of each approach are summarized in Table 1.

Table 1. Main relevant features about entry in the selected approaches

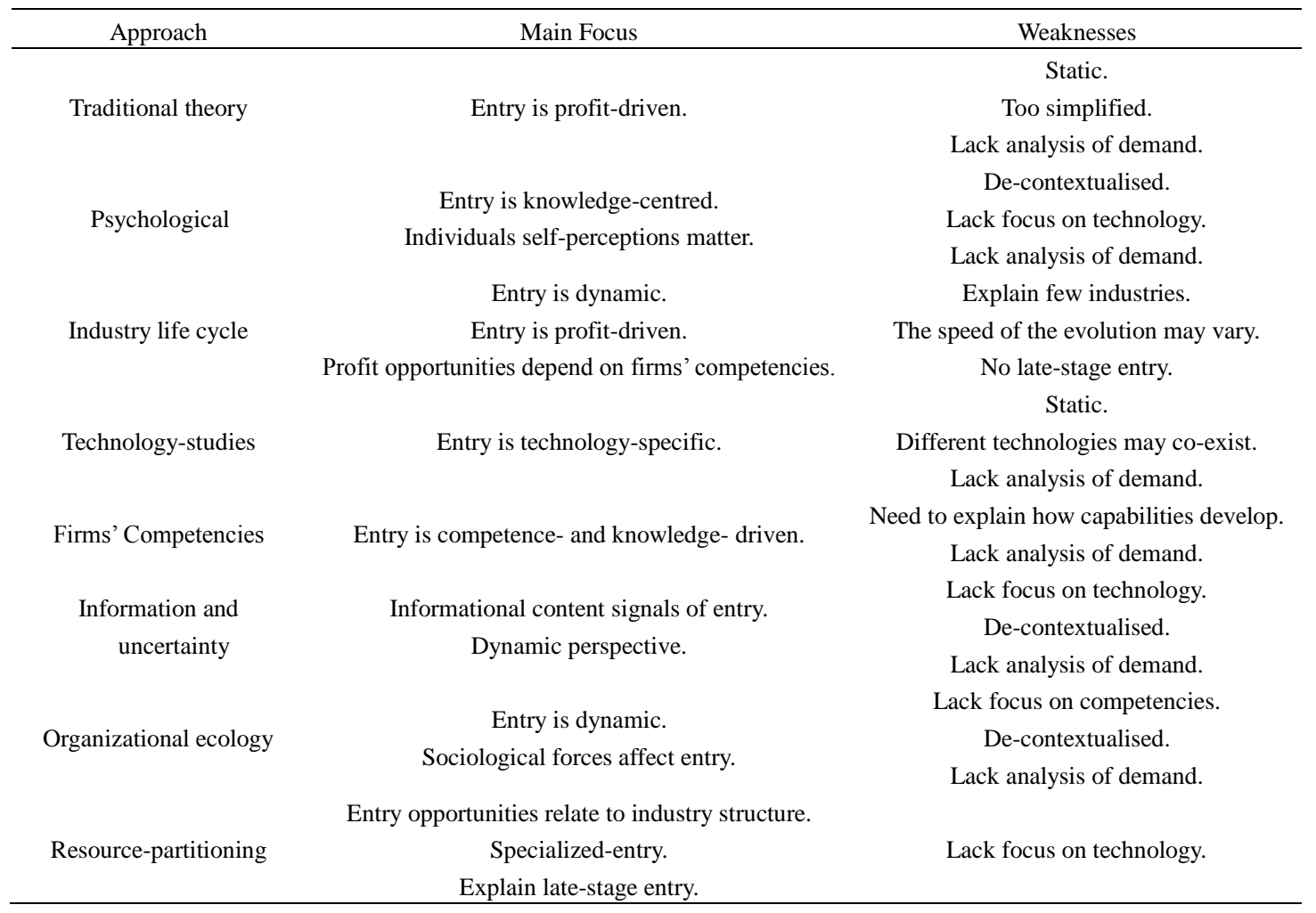

\section{Intertwining the Explanations}

In this section, we take a step forward and develop a framework of study about entry. On the one hand, it is obvious that an attempt at building a single formal model that might take into account all the different determinants and features of such a complex process could not be achievable (Note 6), nor is it likely to be appropriate. On the other hand, neither a single feature nor a model is adequate to grasp the multifaceted nature of entry and entrepreneurship. What we believe to be fruitful for researchers in these areas is to establish a cross-fertilization among the concepts and theories we discussed. Each theory we discussed presents a different perspective and method. Notwithstanding the differences, we propose a framework of analysis in order to make a progress toward the understanding of entry by intertwining the logic of each discipline. Ireland and Webb (2007) and Short (2009) claim that outlining contributions from different fields can make for an excellent contribution to review a complex phenomenon: insightful differences in how related academic disciplines frame and study entrepreneurship can create new knowledge for framing future research studies. In short, the goal of this section is to identify how these contributions might help to spawn future interdisciplinary research to investigate the complexity of entry and IE (Ireland \& Webb, 2007). Therefore, the purpose of this section is not the development of a single framework or model. Our goal is to go back over the discussions presented in section 2 and intertwine relevant features we put forth in the analysis of the theories, by proposing a critical interpretative qualitative framework. We claim that analysing how these different theoretical lenses go along with each other gives an 
original contribution for deepening the lines of research about entry and IE.

Our framework of analysis builds on the following three basic elements:

Element I-Traditional theories and the profit-incentive mechanism: The opening element upon which we base our argument is that the traditional theory explaining entry, both of new firms and of firms into new international markets, as an incentive-driven phenomenon is at the heart of all the models. All the studies recognize, or at least imply, that people enter because they believe they will be able to make profits: It would be hazardous to think about entry without considering profit opportunities. Therefore, our discussion starts with the reconsideration of equation 1 ,

$$
E_{j t}=\gamma\left(\Pi_{j t}^{e}-b_{j}\right)+\varepsilon_{j t},
$$

discussed in the traditional approach. This approach reveals to be too stylised in order to cope with the complexity of entry and IE. Our analysis integrates the features of other contributions that enable us to explain what lies behind three relevant factors: $\Pi_{j t}^{e}$, the degree of entry barriers $b$, and the speed of adjustment of entry to profit opportunities $\gamma$.

Element II-Contextualization: The second element we consider central in all theories is that entry and IE are strongly contextualized. The specific environment and background which define the technological and institutional features of the targeted industry are crucial elements which shape the process of entry and IE. Our analysis focuses on the role of technology in influencing the context of entry.

Element III-Dynamics: The third considers how entry and IE change according to the changing context and historical processes. Entry and IE are dynamics: We claim that entry and IE are rooted phenomena that can only be fully understood with reference to these aspects (Mason \& Harvey, 2013).

The discussion is organized with regard to Figure 7.

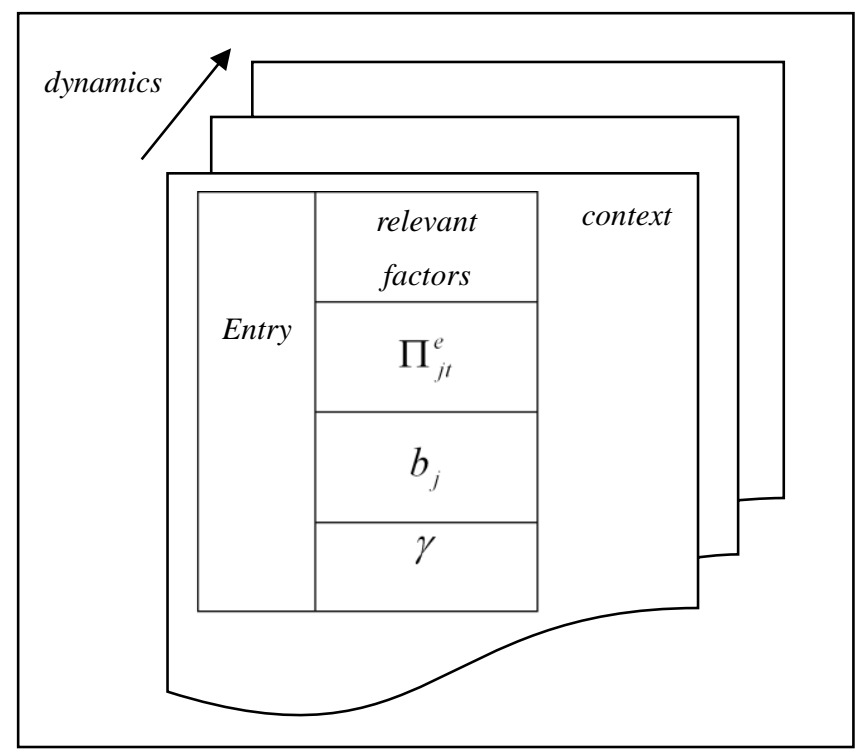

Figure 7. A proposed entry and IE framework

\subsection{Traditional Theories and the Profit-Incentive Mechanism}

The purpose of making profits represents the basic impelling vital force of entry and IE along the whole path of evolution of the industry. In order to understand entry and IE, then, what we really need to investigate is why potential entrants consider their expected level of profits after entry has occurred sufficient to cover the entry cost.

\subsubsection{Profits, Industry Life Cycle, and Technological Competencies}

We identify the basic relevant explanation in the industry life cycle model which argues that each i-th firm is characterised by given capabilities and innovative expertise $s_{i}$ and firm's expected profit (which now we rewrite specifying that is related to the i-th firm: $\Pi_{i j t}^{e}$ ) is a function of this expertise. These capabilities are associated 
with the innovative skills in terms of both technological product and process innovation. The theory of technological regimes reinforces the argument, emphasising how firms' expertise and capabilities are strongly linked to the current state of the technology in the industry and by any technological change: technological capabilities and entry opportunities are determined by the characteristics of the technological environment (i.e. technological regime) as well as by the changes in technology. When the industry is characterised by a change that negatively affects the existing competencies in the industry and requires a new kind of technological skills, then what we called innovative expertise plays a different role compared to that in the situation of a competence-enhancing shock, as discussed in section 2.5. In the first case, more firms will think themselves capable of holding the required new competencies, anticipate positive $\Pi_{i j t}^{e}$, and thus new possibilities for both "greenfield" entrants and diversifying firms open up. In this situation, in IE, born-globals are more likely to emerge. In the latter case, the competencies gap that new potential entrants suffer increases and consequently the decision to enter the market is tougher.

Innovation and technology studies extensively debated on how firms' technological competencies and the technological features of a given industry influence entry decisions and IE. The figure of the "innovator entrepreneurs", motivated by profit opportunities associated with the introduction of the new technology and by their creative personality, shapes the dynamics of industries. Along this line, innovation capabilities, both in terms of product and process innovation, are the key element in explaining why some potential entrants consider their $\Pi_{i j t}^{e}$ sufficient to cover the entry cost, thus entering the industry or a new foreign market. Researches about entry and IE need then to focus on the development of capabilities which make entry profitable. Investigations of prior knowledge and of the development of capabilities in the pre-entry period becomes crucial in order to understand the identification, creation and exploration of profit opportunities, and as a consequence to understand entry and IE. The better the correspondence between the required knowledge and capabilities of the technology of the industry to enter and the pre-entry capabilities of a potential entrant, the more likely a firm will decide to enter the market, as shown by Helfat and Lieberman (2002). These results suggest that if we aim at understanding entry, we need to understand the capabilities and resources that preceded and induced entry. We return on these aspects in section 4.

\subsubsection{Profits, Resource-Partitioning, and Technology}

Product innovation and process innovation usually follow different strategies in order to successfully enter a new market: The former is more dedicated to differentiation strategies while the latter to cost reduction. The resource-partitioning model fruitfully extends these considerations. As the concentration in one market increases because of product standardization, new local and international firms might expect $\Pi_{i j t}^{e}>0$ by differentiating their products. In this sense, entry and IE are a competence-driven phenomenon, that is to say, firms which are able to recognize the opportunities and introduce new variants of the standard product may find entry and IE profitable. In this context, the resource-partitioning model explicitly considers the co-existence of heterogeneous firms: adopting the concept of strategic groups, it is possible to identify in a given population different types of organizations which can co-exist in the market: Generalist and specialist firms. Each of these groups pursues different strategies: Generalist domestic firms and foreign international generalist firms which basically compete on costs, producing a standardized product, on the one hand, and specialist domestic and foreign international firms which compete on product differentiation, on the other hand. Accordingly $\Pi_{i j t}^{e}, b, \gamma$ significantly differ for these diverse groups of firms, and different entry patterns, IE opportunities and strategies emerge. Carroll and Swaninathan (1992, 2000), Swaminathan (1995), Mezias and Mezias (2000) provide empirical support about product differentiation of entering firms in the brewing, wine and film industries. McDougall et al. (2003) give evidence showing how international new ventures choose to compete through differentiation strategies, as opposed to low cost strategies. Moreover, being these activities related to market niches, it comes out a picture where international new ventures tend to enter various foreign markets in order to increase sales volumes.

For having the $\Pi_{i j t}^{e}$ in a market niche, where demand is small by definition, we necessarily require that the level of entry barriers associated with $b_{j}$ is low. The resource-partitioning model would benefit from considering the technological aspects of this process: If a technology with lower entry fixed costs enables firms to enter at a small scale by pursuing differentiation strategies, then the exploitation of late-stage opportunities is explained. The cases of the late-stage entry of microbreweries and farm wineries in US (Carroll \& Swaninathan, 1992, 2000; Swaminathan, 1995) are clear examples. Intertwining the technology studies and the resource-partitioning approach might be mutually useful. The resource-partitioning story needs a deeper understanding of the technological aspects and the technological approach should consider the entry opportunities, strategies and modes generated by the co-existence of diverse technologies. If we simply represent technology with the total cost function, like e.g. $T C=c q+F$ (where $q$ indicates the quantity produced, $c$ the variable cost and $F$ the fixed 
cost), the development of a new technology characterized by $T C^{\prime}=c^{\prime} q+F^{\prime}$, with $F^{\prime}<F$ and $c^{\prime}>c$ (i.e. lower entry barriers, but lower possibilities to exploit economies of scale), would lead to expect $\Pi_{i j t}^{e}>0$ and open entry opportunities for new specialized firms as in the case of late-stage entry.

\subsubsection{Profits, Industry Life Cycle, and Information Disclosure}

The theories about information and uncertainty would also intertwine well with the industry life cycles for a more comprehensive picture. The idea in industry life cycle models that firms are heterogeneous because endowed with different expertise $s_{i}$ is useful for explaining that firms respond differently to the market opportunities and stimuli: It follows that the model is able to predict that entrants are different among them and enter a market at dissimilar initial sizes. The explanation of this empirical pattern might benefit by integrating the explanation given by the studies about the role of information and uncertainty: Those entrants with higher expectations about $\Pi_{i j t}^{e}$ choose to enter with larger initial capacity. Being more confident about their future viability and profitability, they find it more advantageous to enter the industry making a larger initial commitment in terms of investment in production capacity. The same holds when we consider the mode of entry into a foreign market: Different entry modes reflect different degree of resource commitments and risk for the firm (Burgel \& Murray, 2000). Firms that hold higher positive expectations about future profits in the market start out with higher degree of commitments. This behavior brings our attention to the concept of "real options": Firms, holding different information and consequently different expectations about the future, may start small, keeping a real option to invest in the subsequent periods if the early results are profitable. This behavior and this kind of self-selected variation in commitments among firms is supported by empirical evidence (see, among others, Mata, 1996; Dunne et al., 1988; Audretsch \& Mahmood, 1995; Lippman \& Rumelt, 1982). This simple explanation introduces heterogeneity in the industry life cycle models which might explain also why firms with similar capabilities have different sizes. Thus, firms' heterogeneity in entry and IE is explained not only by existing capabilities $s_{i}$ but also by different expectations about the viability and potentiality of $s_{i}$.

The industry life cycle evolution is strongly determined by the phenomenon of mass entry in the early stages. Again, this aspect would benefit from considering the role of information and uncertainty which explain entry and the speed of entry. The speed of entry in industry life cycle models is simply related to the introduction of new variants of the existing product in the early phase of the industry evolution, when uncertainty is relatively high. When the industry product becomes more standardized the process of entry slows down and eventually stops. With regard to the speed of adjustment of entry to profit opportunities $\gamma$, the studies about the role of information and uncertainty brings into the analysis the importance of the informational content of signals: when this is high, small amounts of new information might induce significant shifts in posterior beliefs, that might ultimately translate into fast entry and mass phenomena. This consideration is crucial if we consider that, in this context, the action of entering, revealing the post-entry performance of the firms, discloses additional information that serves to resolve the uncertainty related to the market profitability. As seen in Figure 3 in section 2.6., the process of entry is a function of the informational structure that characterises the industry.

\subsubsection{Psychological and Legitimization Effects}

In addition, to investigate the speed of adjustment of entry to profit opportunities $\gamma$ researchers would benefit from intertwining the explanations of other relevant approaches: Over-confident behaviours of the psychological studies and the legitimization effect of the organizational ecology approach. Over-confident behaviours are associated with the exploration of new organizational forms, new techniques, new innovations, exploration of new markets, and, in general, with new ways of doing something. In the absence of these trials and errors, there would not be new information about novelties and new opportunities. Therefore, the higher the over-confidence the faster the process of legitimization in an industry: In the end, the faster the entry process. Related to this, the more of a given type (i.e. producing a given variant of the relevant product, or a given type of organisational form, or a mode of entering a foreign market) of firms that enter a market, the more "acknowledged", "usual" and "informative" this phenomenon becomes. As the ecological approaches claim, there is legitimization effect on work, that gives "credibility" and "trust" to new potential entrants, the more new entrants that decide to enter. In particular, this effect plays a larger role when the number of firms of a given type is small, that is to say in the birth epoch of the industry evolution, or in situations in which uncertainty is higher. By intertwining the positive externalities of over-confident behaviours in exploring new ways of doing something, the consequent spread of information and the decrease in the degree of uncertainty, which facilitate new entry, which in turn, thank to the legitimization effect, reinforces the process, as in a virtuous cycle, then we get a more robust and convincing explanation about what characterizes new firms' decisions in the mass entry period. How the legitimization and psychological effects are linked to the characteristics of the technology is an interesting, but lacking, issue. Technological complexity might significantly influence the dynamics of legitimization and the over-confident 
behaviours, thus influencing the dynamics of entry in the end. This topic deserves more future research.

\subsubsection{Profits, Psychological Effects and Information}

Consider also the cross-fertilization of bringing into the discussion the contribution of the psychological studies in interpreting and assessing $\Pi_{i j t}^{e}$. When considering the entry decision and IE, the firm's (potential) innovative capabilities $s_{i}$ are 'self'-evaluated, in the sense that the entry decision is taken based on what entrepreneurs think of themselves: The personal perception of the opportunities in the industry, and the beliefs about the owned competencies strongly influence the decision of entry, the entry mode, the size and the country of entry. In this sense, over-optimistic and over-confident behaviours play a significant role in the explanation of $\Pi_{i j t}^{e}$ and consequently of the entry process. Consider how over-confident entrepreneurs contribute positively to the evaluations of $\Pi_{i j t}^{e}$ and to social welfare. Over-confident entrants, even if after some periods they exit the market, representing in this way a waste of resources from a social point of view, are a benefit to the society as a whole (Bernardo \& Welch, 2001; Dosi \& Lovallo, 1997). Exploring new ways of doing something reduces the probability of having phenomena of lock-in and possible local path-dependency to sub-optimal equilibria. Superior innovations might diffuse if there were overoptimistic entrepreneurs who pay the price of the initial exploration: Their failure opens the way to the takeoff of the industry (Dosi \& Lovallo, 1997). If we consider a model of herd behaviour (or informational cascade), in which two types of individuals, normal ones and entrepreneurs (over-confident individuals that are more likely to follow their signal, disregarding other people's public choices), are asked to undertake an action or not on the basis of their signals, it emerges that in the absence of entrepreneurs the phenomenon of herd behaviour soon emerges in the decision process and individuals typically end up following the same action regardless of their private signal, thus revealing no new information to the public (Bernardo \& Welch, 2001). On the contrary, in the presence of over-confident individuals, it is more likely that the chain of herd behaviour will be broken, in this way avoiding the pitfall that the whole society could converge on the incorrect (or inferior) choice (wrong informational cascade). Hence, the probability of a group of people making a wrong decision is shown to be a decreasing function of the proportion of entrepreneurs in the group. From this point of view, "irrational over-confident entrants", providing additional valuable information to the group, and thus better information to estimate $\Pi_{i j t}^{e}$, represent a positive externality for the economy. Also, errors in the mode or timing of entry of foreign markets represent a learning by doing that can change the mindsets of managers thus influencing future IE decisions (Zahra et al., 2005). Then, investigations dedicated to study failures of entries and IE, and their effect on the informational structure for new entrants, become crucial to deepen the understanding of the process of entry and IE.

The psychological investigations also help in enriching some other explanations of other approaches. Traditional theories, as represented in equation 1, require at time $t$ either entry or exit. On the contrary, data show that entry and exit are simultaneous phenomena. The psychological approach might also help us in explaining why some firms enter and other simultaneously exit the market, why entrants are so different in size, which entry mode to firms select in their international strategic moves. Different levels of self-evaluation and confidence among the entrepreneurs who are deciding whether to enter or not, could lead to different behaviours and diverse choices about the appropriate size of entry, entry mode and which country to enter. Sommer (2010) conducts an empirical investigation in which he shows that the most significant predictor of the intention to become international is the conviction to possess the necessary capabilities: The cognitive aspect of self-efficacy, then, is clearly relevant both for new entry and IE. Moreover, considering the fear of failure in certain cultures the shame involved by the failure (Shepherd, 2003; Lee et al., 2007), it is possible to interpret why foreign firms may act faster upon an opportunity if compared to local firms. This might also explain in the studies about information and uncertainty why after mass-entry we register a shakeout phenomenon without referring to a stability of the hazard function over time as in section 2.6., and why the empirical evidence show that many new entrants at time $t$ are not able to survive and consequently exit the market after a few years, say $t+\tau$, with $\tau>0$ (Baldwin \& Gorecki, 1989; Dunne et al., 1988; Geroski, 1995). This evidence suggests that there might be too much confidence among new entrants at $t$, such that after a few periods in which entry has occurred, these firms realize that they are not endowed with the required sufficient level of competencies to be in the market, being forced then to quit.

The psychological studies would benefit too from cross-fertilizing with other approaches. People enter because they believe they will be able to make profits: Psychological investigations should deepen the understanding of the reasons why over-confident entrepreneurs seem to behave as if they were thinking that on average people lose money while they will not (Dosi \& Lovallo, 1997). Is it because of pre-entry experience of entrepreneurs, as discussed above? Is it related to entrepreneurs education? Is it dependent on the degree of technological complexity in the industry? How is this linked to the degree of information and uncertainty in the industry? 
Psychological investigations should also consider that the levels of self-evaluation and confidence among the entrepreneurs may vary according to the industry evolutionary stages. The explanations given by the approaches discussed above might be helpful to define the research agenda in the future psychological investigations about entry.

\subsection{Contextualization and Dynamics}

Industries seem to be different from each other and characterised by specific features. The context of analysis, then, need to be properly related to the relevant features of the particular industry under examination. The theories that refer to technological regimes as the mainspring of industries' evolution explicitly require the analysis to be "industry-specific" in order to capture the process underlying the evolution of the relevant technology and of the related market structures. As a consequence, also industry-specific analyses of entry and IE may reveal to be more informative rather than more general studies. Morrison (2006) explicitly claims that the understanding of entrepreneurship is improved by referring to the industry setting, as well as the cultural and organizational context, within which entrepreneurs are embedded. Lin and Nabergoj (2014) emphasize the importance to study the entrepreneurial contexts and the contextual nature of entrepreneurial creativity. Moreover, the context is dynamic: the determinants and all the features that affect the entry process of new firms and IE need to be investigated from a dynamic point of view.

\subsubsection{The Technological Context}

From the discussion in section 2 we take the role of technology as the key factor in determining the specificities of the industries. All the theoretical approaches discussed in section 2 may benefit from explicitly considering in their argumentation the technological specificities of the context under study. For example, overconfident behaviours may vary significantly in contexts of competence-enhancing or competence-destroying conditions thus leading to different entry decisions and entrepreneurial behaviours. The role of information disclosure and uncertainty are also related to the conditions of technological change, thus impacting on the evaluation of the opportunities to enter a market which, in the end, shapes the pattern of entry and IE. The concept of entry barriers in the traditional approach and in the industry life cycle studies considerably relates to technology and technological evolution: Whether technology leads to high chances to exploit economies of scale or not is crucial for determining the degree of entry barriers and entry opportunities; also, whether the impact of technological change on existing competencies is disruptive or not is crucial for reinforcing or undermining existing entry barriers. We require that these considerations related to technology should be more strongly included in the research agenda of the various studies about entry and IE, investigating if entry and internationalization modes, size, timing and strategies present technological invariances or not. This would reveal useful for implementing further successful entry decision strategies.

Industry life cycle dynamics is representative for only some industries while other industries' evolution does not conform to the predictions of the model. Some invariances and causal relationships are responsible for the similar evolution of the television, automobile, tires, and radio industries, defining a context which leads the industrial structures from fragmented to highly concentrated, and the process of entry of firms which peaks early in the development of the market and then fades away. The evolution of the relevant technology, the possibility to exploit economies of scale and cost-advantages, the cumulativeness of innovation, the homogeneity of the demand structure play a driving role in this model in determining entry opportunities and the evolution of market structure (Audretsch, 2002).

The dynamics of the context of the industry life cycle studies should benefit from integrating the role of innovative expertise $s_{i}$ with the changes in the factors which define the technological regimes (technological opportunities, appropriability, cumulativeness and knowledge base.) Explicitly considering the industry life cycle evolution as the shift from a Schumpeter Mark I regime to a Schumpeter Mark II technological regime would give added value to the explanation, considering how $s_{i}$ and $\Pi_{i j t}^{e}$, and consequently entry, change in relation to changes of technological opportunities, appropriability, cumulativeness and knowledge base. Analysing how the conditions of cumulativeness, appropriability and opportunities in a given context change over time is important for understanding the processes of identification, recognition and exploitation of new profit opportunities for new firms and IE. If technology is characterized by a cumulativeness which becomes stronger and stronger then we expect the possibilities of new entry to become tougher and tougher, and vice versa. If technological opportunities decrease as the industry matures then we expect new entry to be related to differentiation strategies or competence destroying changes; otherwise, we expect low (or null) entry rates. If appropriability conditions reinforce as industry matures then we expect entry to be more and more hampered, and vice versa. Combining these industry-specific aspects would represent a greater variety of evolutionary paths of industries' structures, 
entry and IE activities.

In addition, considering successive technological discontinuities during the evolution of an industry rather than only the discontinuity at the birth of the industry would enlarge the possible evolutionary dynamics which industry structure and entry patterns might follow, like the cases of technological succession (Figure 8) (Windrum, 2003; Windrum \& Birchenhall, 2005), as in the semiconductor industry where three different technologies followed one after another: transistors, integrated circuits and microprocessors (Malerba et al., 2008).

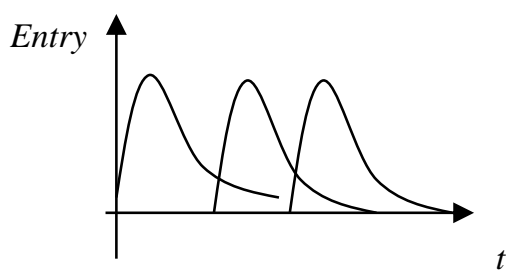

Figure 8. Entry and technological succession

In fact, those industries which follow different evolutionary paths from the classic industry life cycle evolution present different relevant contexts. Considering other features in the industry life cycle story would enlarge the possibility to consider and represent other evolutionary trajectories in industries' evolution and, then, other entry paths (Note 7).

\subsubsection{Technological Context and Heterogeneity}

The industry life cycle studies should benefit from integrating the argument behind the dynamics pointed out by the resource-partitioning theories depicted by the common late-stage entry of new firms: A more comprehensive picture would emerge (Figure 9). When the industry becomes mature, barriers to entry tend to become stronger thus hampering entry; however, the product becomes more and more standardized thus increasing the opportunities for new specialist entrants which focus on differentiation strategies. What is relevant in this explanation is that the basic demand conditions change: When the product is highly standardized, some customers are left unsatisfied at the market niches, thus fostering a new wave of entrants. Considering the demand conditions and the homogeneity/fragmentation of the demand structure should be an important topic both for the industry life cycle and the technological regimes studies in order to better define the entry opportunities in a given technological context and in a dynamic perspective. In addition, we recall here what we pointed out in the previous paragraph about the opportunities related to the development and introduction of a new coexisting technology with a lower entry cost.

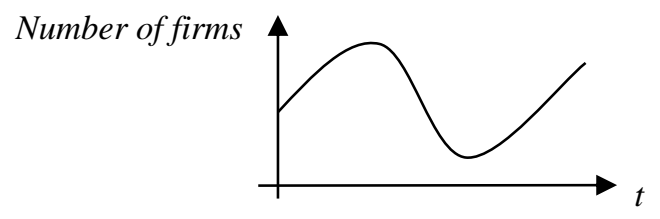

Figure 9. Late-stage entry

What really is lacking in the theories we considered so far is the role of demand and the evolution of demand: Only the resource-partitioning approach considers some rudiments related to demand. Considering the market resource space and the elaboration in the customers' demand which becomes more diversified and sophisticated over time, we have seen that the greater this increase in the resource space dimensionality, the higher the opportunities for new specialist entrants. This means that, since tastes develop over time, then the presence of specialist organizations is more frequent during the late stages of the industry dynamics. All the models we discussed need a stronger role of demand in their explanation.

\subsubsection{Dynamics, Competencies, and the Speed of Entry}

Finally, dynamics is also strongly related to the speed of entry. As already seen in the previous paragraph, intertwining the arguments of the industry life cycle model, of the role of information and uncertainty, of the 
effect of overconfident behaviours, and of the legitimization effect gives a more complete picture about the speed of entry and IE. Furthermore, the speed of entry is closely linked to the nature of pre-entry capabilities: the better the correspondence between the required knowledge and capabilities of the technology and industry to enter and the pre-entry capabilities of a potential entrant, the more likely a firm will decide to enter the market, as shown by Helfat and Lieberman (2002). The authors show how the pre-entry resources and capabilities of firms have an important impact on the markets they choose to enter, the mode and timing of entry and, finally, the success of entry. Also, the correspondence between the required knowledge and the pre-entry capabilities influences the modes of entry and IE: Established firms with critical knowledge gaps are more likely to use modes of entry such as acquisition, joint venture, parent spin-offs. Helfat and Lieberman (2002) also claim that the correspondence between firms' pre-entry resources and the required knowledge profile of the industry also impacts on the survival and successful rates of the firms: they show that the success of entrants is primarily determined by its observable pre-entry capabilities and resources, and less by characteristics that are discovered and generated after entry occurred. Klepper and Simons (2000) show that among the entrants into the U.S. television receiver industry, those who diversified from the radio industry entered earlier, had higher survival rates and gained larger market shares in the TV industry. The TV and radio industries are technologically related such that radio producers exploited their prior experience to enter a new industry producing TV and finally dominate the market. In a study about the U.S. automobile industry, Klepper (2002) show that pre-entry experience, including experience developed in incumbent firms, imparted an enduring advantage, referring in particular to the organizational and managerial experience of the leaders of the firms. Ucbasaran et al. (2009) habitual entrepreneurs may benefit from their prior knowledge to better define IE activities in comparison with novice entrepreneurs. Bell et al. (2003) show the differences in the patterns and pace of entry into foreign markets among knowledge-intensive and traditional firms: the former firms internationalise more rapidly, many from inception, and tend to exploit new networks and resources gained from technological innovations, giving rise to the "born-globals". The traditional firms tend to enter foreign markets in a more incremental manner over a longer period of time focussing on psychically and geographically close markets.

These researches put in evidence the potentials for collaborative research to generate new knowledge intertwining various approaches to understand how capabilities generate and evolve in correspondence to the speed of entry and the dynamics of the industry: Different capability and knowledge contexts impact on the dynamics of the industry. This topic deserves future developments.

\section{Implications and Managerial Considerations}

The discussion we presented centres the discourse on the explanation why some entrepreneurs and firms consider their $\Pi_{i j t}^{e}$ greater than entry costs, thus leading to effective entry and IE. The focus of our argument rests in the investigation of those capabilities which make entry profitable. Three keywords have driven our discussion: Capabilities, technology, dynamics. We further consider these elements in the following considerations.

We showed that entry opportunities and IE activities are technologically-determined contextualized phenomena. Firms' knowledge base and innovative capabilities are the crucial elements which shape the ability to explore and exploit changes in the technological knowledge across industries and in foreign markets. Two considerations are immediately relevant to consider: These technological opportunities are technology-specific and not country-specific, as pointed out by the studies about technology; firm-specific competencies and investments decisions in R\&D follow different phases in accordance with the evolution of the industry, as in the industry life cycle analyses. Two direct implications emerge: When studying entry and IE, we need to consider the development of the technological capabilities which enable entry to be profitable; we need to recognize that these capabilities are industry(-technology)-specific and dynamics. Six managerial considerations emerge.

First of all, entry and IE change according to the changing conditions over the life cycle of an industry. As a consequence, policies of internationalization should also be considered a dynamic activity: Managerial policies need to be defined in a dynamic fashion since the start of internationalization and entry, rather than designing them as a one-off activity (Wright et al., 2007). Different methods of market entry might be chosen according to the different characteristics of the industry and to the stage of the evolution of the industry.

Second, we claim to explicitly consider in managerial strategies the research direction traced by the theories of dynamic capabilities. Dynamic capabilities relate to the ability "to integrate, build, and reconfigure internal and external competencies to address rapidly-changing environments" (Teece et al., 1997). Eisenhardt and Martin (2000) define dynamic capabilities as the set of specific and identifiable processes such as product development, strategic decision making, and alliancing which create value for firms' strategies. The authors point out how 
these strategies are idiosyncratic, although they display commonalties across firms; also, they are unstable, thus requiring the strategic imperative to be change rather that leverage. Knowledge is not given and the implementation of entry opportunities recognition and exploitation need to shift the focus from the processes through which use of a knowledge endowment to identify and explore opportunities to the processes through which knowledge is accumulated and developed in order to discover, grasp and create opportunities for effective entry and IE. Managerial practices need to be tailored on the creation of researches and routines to guide knowledge development in the direction of opportunity identification, creation and exploitation. In line with this, Kogut and Zander (1992) refer to the concept of combinative capabilities as the engine of firms' success: Combinative capabilities are firms' processes through which they obtain and combine knowledge to generate new applications and continuous adaptation to changes in the context. This capacity bridges between the firm ability to take advantage of its knowledge and the unexplored potential of the technology (Kogut \& Zander, 1992). For example, in an empirical analysis, Prasertsakul (2013) shows that dynamic capabilities of pursuing a proper combination of alignment and adaptation strategies simultaneously improve profitability and export performance of exporting firms. Those managements who have invested in the development of dynamic capabilities may find themselves advantaged with compare to those who have invested in routinizing the responses to change. Deliberate investments in processes of organizational learning thus can enable the development and adjustment of dynamic capabilities for the management of acquisitions, alliances or international entrepreneurial activities, for example (Winter, 2003).

Third, we claim the need to devote greater emphasis to investigate the role of prior knowledge and the development of capabilities in the pre-entry period: We require knowledge about these aspects if we are to understand entry. Consider, among others, the significant abovementioned contributions given by Klepper and Simons (2000), Helfat and Lieberman (2002), Klepper (2002), Ucbasaran et al. (2009). These considerations bring us to suggest that studying capabilities only at firm-level may not be sufficient: Individual-level research is needed to identify the characteristics of those entrepreneurs who are key to internationalization, in the case of owner-managed firms, as well as to understand which individuals are influential in the board of directors to develop internationalization strategies. The design of strategies of entry and internationalization, the ability to identify and exploit opportunities, the attitude towards network creation, the knowledge of the local markets are key factors for implementing a successful strategy. Given that these aspects are closely related to the characteristics of individual managers, the organization of a good board of individuals is the crucial ingredient before engaging in effective entry and IE activities: Recruiting local managers may prove to be fruitful, in particular in those markets where knowledge is mostly tacit; network strategies with experienced entrepreneurs also may reveal to be successful.

Fourth, we discussed how the nature of technological change may affect, positively or negatively, existing competencies and expertise in the industry thus facilitating or hampering new firms. When technological change is more radical newcomers and inexperienced teams may benefit most implementing new strategies, while established routines may suffer from lock-ins. To cope with technological change, the board of directors should explicitly consider to organize teams of managers together with engineers and technicians with different skills and capabilities in the design of entry and internationalization modes and strategies, as well as invest in networking both at the individual and at the firm level, in order to acquire a complete portfolio of competencies to cope with such complexity. Further to these concepts, according to Henderson and Clark (1990), and Henderson (1993), there are cases in which the disruptive effects on firms' competencies are due to innovations and changes in the so-called "architecture" of the products rather than in their technological aspects (Note 8): What changes is not the technological base but the relationships and the hierarchy of the components and parts that make the product. If the incumbents focus on the existing architectures, underrating the importance of the new ones, then it could happen that new firms come into the market and succeed. The argument of Henderson and Clark is closely linked to the informational and knowledge changes inside a firm. In fact, important concepts strictly related to the architecture of the product include the knowledge reflecting the problem-solving capability and the managerial procedures of the architecture itself. Examples include implicit and explicit informational channels inside the organisation, procedural routines, and the communication practices among researchers and engineers. In cases of emergence of a new architecture, established firms tend to merely modify and not radically change their procedures, such that they end up in a situation of disadvantage compared to the newcomers that calibrate their structure on the new architecture.

Fifth, contexts are heterogeneous: This consideration requires heterogeneous approaches and strategies according to the specific market and specific technology under inspection. This imply that a single board of directors and managers may not be appropriate for exploiting opportunities, defining modes of entry and elaborating strategies 
for successful entry and IE. Designing different teams for different markets is more crucial the more heterogeneous the tailored markets are. Creating different international networks and involving local managers embedded in the local market may be an effective strategy to follow, in particular in the early phase after entry and/or internationalization, when the degree of uncertainty is higher; the degree of legitimization in the foreign markets may influence firms' survival: The liability of foreignness effect requires the implementation of tailored strategies to overcome the reluctance towards newness in order to successfully enter into a foreign market. In these cases, the recruitment of local managers and the development of network alliances are useful insights for the top management (Huang \& Jarinto, 2015) and the lacking of competent international managers may become a serious impediment to firms' internationalization (e.g. as reported in the case of Jiaxing firms in China by Zhang \& Dai, 2013).

Finally, the results after entry has occurred are uncertain by nature, given that firms are bounded rational actors and that market conditions constantly change over time. Looking at the experience of other entering firms, then, is helpful and informative, as pointed out by the studies about information and uncertainty. When new firms decide to enter the market, as well as when established firms decide to enter a new international market, new information about the characteristics of the market, consumers' preferences, degree of competition, profit opportunities, and so on, is publicly revealed more quickly. Then, when entry and IE are high, more firms can resolve their uncertainty more easily and may decide to enter and internationally expand, leading to the phenomenon of informational cascade and to a positive trials and error effect. Studies about other firms' experiences need to be explicitly consider into the tasks of the management.

\section{Conclusions and Future Developments}

Entry and IE are multifaceted and complex phenomena. Several studies from multiple disciplines and theories have already addressed these topics. However, the analyses have been mostly focused on issues specific to their discipline's domain underestimating the potentials of cross-disciplinary collaborations. The contribution of this paper is to propose a framework of study for deepening the knowledge about entry and intertwining the potentials of various approaches. Each single theoretical model is too simplified and restrictive to be able to capture the complexity related to entry as well as no single view reveals appropriate in the conceptual interpretation of internationalisation (Coviello \& McAuley, 1999; Ireland \& Webb, 2007). Therefore, this paper debates the integration of different approaches to explain entry and IE: our critical discussion results in some fruitful intertwinements among the different relevant features about entry. We believe that this paper could spawn and encourage new future collaborative and interdisciplinary research to create additional knowledge about entry and IE.

The development of our framework is related to the investigation of what determines $\Pi_{i j t}^{e}$ in a contextualized technological dynamic environment. Firm's capabilities and expertise $s_{i}$ are the key force of our argument. We discussed how these capabilities are strongly determined by technology and technological change. We claim that prior knowledge in the pre-entry periods plays a crucial role in shaping the development of the necessary capabilities after entry: The better the match the required capabilities of the industry to enter and the pre-entry capabilities of the entrant, the more likely entry will occur, and the higher the successful rate. Consider that pre-entry capabilities are self-evaluated such that overconfident behaviours may induce entrants to suffer from cognitive biases, being excessively optimistic about their real capabilities, thus being forced to failure and to exit the market after few periods. However, this waste of resources brings also a positive externality to the society as a whole because overconfident trials and errors disclose new useful information for subsequent entry. The role of information disclosure explains the entry patterns and especially mass entry phenomena. During the waves of entry a legitimization effect is at work, which reinforces the process of entry. We conclude that changes in the technological context generate new opportunities which may stimulate new dynamics.

Our results give also a contribution to managerial implications for tailoring appropriate strategies. To sum up, we suggest: 1) internationalization strategies need to be defined in a dynamic fashion; 2) managements need to invest in the development of dynamic capabilities: The strategic imperative is change rather that leverage; 3) potential entrants need to deep analyse the correspondence between the required capabilities of the industry to enter and their pre-entry capabilities: Their success is a function of this match; 4) in order to manage technological change, the management needs to organize teams of managers together with engineers and technicians in the design of entry and internationalization modes and strategies, as well as invest in networking; 5) entering different markets or countries requires different strategies and then different management teams; 6) learning from other experiences, benefiting from new information, and the ability of coping with uncertainty should be explicit management's tasks. 
The study presented in this paper does not aim to be comprehensive. Further developments of the paper would be desirable. First of all, additional theoretical work which enlarges the spectrum of analysis would be beneficial by bringing into the discussion more relevant factors which contribute to strengthen the explanation of entry and IE. Second, a more international perspective of the discussion would be desirable, studying more cases of IE which can highlight and support the features discussed in the framework of this paper. Finally, an empirical counterpart of this analysis may give more insights. Our discussion incentivises industry-specific studies: These would lead to a deeper comprehension of the real determinants of entry and IE. Also, considering regional differences and local markets' idiosyncratic characteristics would be important.

\section{References}

Abernathy, W., \& Utterback, J. (1978). Patterns of Industrial Innovation. Technology Review, 80(7), 41-47.

Acs, Z. J., \& Audretsch, D. B. (2003). An Interdisciplinary Survey and Introduction. Handbook of Entrepreneurship Research. Springer.

Anderson, P., \& Tushman, M. (1990). Technological Discontinuities and Dominant Designs: A Cyclical Model of Technological Change. Administrative Science Quarterly, 35(1), 604-633. http://dx.doi.org/10.2307/2393511

Audretsch, D. (1995). Innovation and Industry Evolution. Cambridge, MA: The MIT Press.

Audretsch, D. (2002). The Dynamic Role of Small Firms: Evidence from the U.S.. Small Business Economics, 18(1), 13-40. http://dx.doi.org/10.1007/978-1-4615-0963-9_2

Audretsch, D., \& Mahmood, T. (1995). New Firm Survival: New Results Using a Hazard Function. The Review of Economics and Statistics, 77(1), 97-103. http://dx.doi.org/10.2307/2109995

Autio, E., Sapienza, H. J., \& Almeida, J. G. (2000). Effects of age at entry, knowledge intensity, and imitability on international growth. Academy of Management Journal, 43(5), 909-924. http://dx.doi.org/10.2307/1556419

Bain, J. (1956). Barriers to New Competition. Cambridge Mass: Harvard University Press. http://dx.doi.org/10.4159/harvard.9780674188037

Baldwin, J., \& Gorecki, P. (1989). Firm Entry and Exit in the Canadian Manufacturing Sector, 1970-1982, Canadian Journal of Economics, 24(2), 300-323. http://dx.doi.org/10.2307/135625

Banerjee, A. (1992). A Simple Model of Herd Behavior. Quarterly Journal of Economics, 107(3), 797-818. http://dx.doi.org/10.2307/2118364

Barbosa, N. (2003). What drives new firms into an industry? An integrative model of entry. Working Paper Series No.23, Núcleo de Investigação em Microeconomia Aplicada,Universidade do Minho. Retrieved from http://www3.eeg.uminho.pt/publications/NIMAwp23.pdf

Barnett, W. (1997). The Dynamics of Competitive Intensity. Administrative Science Quarterly, 42(1), 128-160. http://dx.doi.org/10.2307/2393811

Bell, J., McNaughton, R., Young, S., \& Crick, D. (2003). Towards an Integrative Model of Small Firm Internationalisation. Journal of International Entrepreneurship, 1(4), 339-362. http://dx.doi.org/10.1023/A:1025629424041

Bernardo, A. E., \& Welch, I. (2001). On the Evolution of Overconfidence and Entrepreneurs. Journal of Economics \& Management Strategy, 10(3), 301-330. http://dx.doi.org/10.1162/105864001316907964

Bikhchandani, S., Hirshleifer, D., \& Welch, I. (1992). A Theory of Fads, Fashion, Custom, and Cultural Change as Informational Cascades. Journal of Political Economy, 100(5), 992-1026. http://dx.doi.org/10.1086/261849

Boone, C., Bröcher, V., \& Carroll, G. (2000). Custom Service: Application and Tests of Resource-partitioning Theory among Dutch Auditing Firms from 1896 to 1992. Organization Studies, 21(2), 355-381. http://dx.doi.org/10.1177/0170840600212003

Brüderl, J., Preisendörfer, P., \& Ziegler, R. (1992). Survival Chances of Newly Founded Business Organizations. American Sociological Review, 57(2), 227-242. http://dx.doi.org/10.2307/2096207

Bruyat, C., \& Julien, P. A. (2001). Defining the field of research in entrepreneurship. Journal of Business Venturing, 16(2), 165-180. http://dx.doi.org/10.1016/S0883-9026(99)00043-9

Bull, I., \& Willard, G. E. (1993). Towards a Theory of Entrepreneurship. Journal of Business Venturing, 8(3), 
183-195. http://dx.doi.org/10.1016/0883-9026(93)90026-2

Burgel, O., \& Murray, G. C. (2000). The International Market Entry Choices of Start-Up Companies in High-Technology Industries. Journal of International Marketing, 8(2), 33-62. http://dx.doi.org/10.1509/jimk.8.2.33.19624

Butler, J. E., Doktor, R., \& Lins, F. A. (2010). Linking International Entrepreneurship to Uncertainty, Opportunity, Discovery, and Cognition. Journal of International Entrepreneurship, 8(2), 121-134. http://dx.doi.org/10.1007/s10843-010-0054-x

Carroll, G. (1985). Concentration and Specialization: Dynamics of Niche Width in Populations of Organizations. American Journal of Sociology, 90(6), 1262-1283. http://dx.doi.org/10.1086/228210

Carroll, G. (1997). Long-term Evolutionary Change in Organizational Populations: Theory, Models and Empirical Findings in Industrial Demography. Industrial and Corporate Change, 6(1), 119-143. http://dx.doi.org/10.1093/icc/6.1.119

Carroll, G., \& Hannan, M. (1995). Organizations in Industry: Strategy, Structure \& Selection. Oxford University Press.

Carroll, G., \& Swaminathan, A. (1992). The Organizational Ecology of Strategic Groups in the American Brewing Industry from 1975 to 1990. Industrial and Corporate Change, 1(1), 65-97. http://dx.doi.org/10.1093/icc/1.1.65

Carroll, G., \& Swaminathan, A. (2000). Why the Microbrewery Movement? Organizational Dynamics in the US Brewing Industry. American Journal of Sociology, 106(3), 715-762. http://dx.doi.org/10.1086/318962

Casson, M. (1982). The Entrepreneur: An Economic Theory. Edward Elgar Publishing.

Caves, R. E. (1998). Industrial Organization and New Findings on the Turnover and Mobility of Firms. Journal of Economic Literature, XXXVI(4), 1947-1982.

Caves, R. E., \& Porter, M. (1977). From Entry Barriers to Mobility Barriers: Conjectural Decisions and Contrived Deterrence to New Competition. Quarterly Journal of Economics, 91(2), 241-262. http://dx.doi.org/10.2307/1885416

Cooper, A., Woo, C., \& Dunkelberg, W. (1988). Entrepreneurs Perceived Chances for Success. Journal of Business Venturing, 3(2), 97-108. http://dx.doi.org/10.1016/0883-9026(88)90020-1

Coviello, N. E., \& Jones, M. V. (2004). Methodological Issues in International Entrepreneurship Research. Journal of Business Venturing, 19(4), 485-508. http://dx.doi.org/10.1016/j.jbusvent.2003.06.001

Coviello, N. E., \& McAuley, A. (1999). Internationalisation and the smaller firm: A review of contemporary empirical research. Management International Review, 39(3), 223-256. Retrieved from $\mathrm{http}: / / \mathrm{www}$. freepatentsonline.com/article/Management-International-Review/57590760.html

Cumming, D., Sapienza, H. J., Siegel, D. S., \& Wright, M. (2009). International entrepreneurship: Managerial and policy implications. Strategic Entrepreneurship Journal, 3(4), 283-296. http://dx.doi.org/10.1002/sej.75

Davidsson, P. (2005). Researching Entrepreneurship. Springer.

Dosi, G., \& Lovallo, D. (1997). Rational Entrepreneurs or Optimistic Martyrs? Some Considerations on Technological Regimes, Corporate Entries and the Evolutionary Role of Decision Biases. In R. Garud, P. Nayyar, \& Z. Shapira (Eds.), Technological Innovation: Oversights and Foresights. Cambridge University Press.

Duetsch, L. (1984). An Examination of Industry Exit Patterns. Review of Industrial Organization, 1(1), 60-68. http://dx.doi.org/10.1007/BF02354135

Dunne, T., Roberts, M., \& Samuelson, L. (1988). Patterns of Firm Entry and Exit in U. S. Manufacturing Industries. Rand Journal of Economics, 19(4), 495-515. http://dx.doi.org/10.2307/2555454

Eisenhardt, K., \& Martin, J. (2000). Dynamic capabilities: What are they? Strategic Management Journal, 2l(10-11), http://dx.doi.org/10.1002/1097-0266(200010/11)21:10/11<1105::AID-SMJ133>3.0.CO;2-E

1105-1121.

Gartner, W. B. (1985). A Conceptual Framework for Describing the Phenomenon of New Venture Creation. Academy of Management Review, 10(4), 696-706.

Gartner, W. B. (1988). 'Who is an entrepreneur?' is the wrong question. American Journal of Small Business, 
12(4), 11-32.

Geroski, P. (1995). What do we know about entry? International Journal of Industrial Organization, 13(4), 421-440. http://dx.doi.org/10.1016/0167-7187(95)00498-X

Ghemawat, P. (1987). Investment in lumpy capacity. Journal of Economic Behaviour and Organization, 8(2), 265-277. http://dx.doi.org/10.1016/0167-2681(87)90008-4

Gort, M., \& Klepper, S. (1982). Time Paths in the Diffusion of Product Innovations. Economic Journal, 92(367), 630-653. http://dx.doi.org/10.2307/2232554

Götz, G. (2002). Sunk Costs, Windows of Profit Opportunities, and the Dynamics of Entry. International Journal of Industrial Organization, 20(10), 1409-1436. http://dx.doi.org/10.1016/S0167-7187(02)00006-1

Hannan, M., \& Freeman, J. (1984). Organizational Ecology. Cambridge Mass: Harvard University Press.

Henderson, R., \& Clark, K. (1990). Architectural innovation: The reconfiguration of existing product technologies and the failure of established firms. Administrative Science Quarterly, 35(1), 9-30. http://dx.doi.org/10.2307/2393549

Helfat, C., \& Lieberman, M. (2002). The Birth of Capabilities: Market Entry and the Importance of Pre-history. Industrial and Corporate Change, 11(4), 725-760. http://dx.doi.org/10.1093/icc/11.4.725

Horvath, M., Schivardi, F., \& Woywode, M. (2001). On industry life-cycles: Delay, entry, and shakeout in beer brewing. International Journal of Industrial Organization, 19(7), 1023-1052. http://dx.doi.org/10.1016/S0167-7187(01)00062-5

Huang, D., \& Jarinto, K. (2015). Entry Mode Decision Factors Contemplated by Chinese Consulting Firms. International Business Research, 8(5), 252-261. http://dx.doi.org/10.5539/ibr.v8n5p252

Ibrahim, A. B. (2004). Internationalization: Motive and process. In L. P. Dana (Ed.), Handbook of Research on International Entrepreneurship. Edward Publishing. http://dx.doi.org/10.4337/9781845420512.00016

Ireland, D., \& Webb J. W. (2007). A Cross-Disciplinary Exploration of Entrepreneurship Research. Journal of Management, 33(6), 891-927. http://dx.doi.org/10.1177/0149206307307643

Johanson, J., \& Vahlne, J. E. (1977). The Internationalization Process of the Firm-A Model of Knowledge Development and Increasing Foreign Market Commitments. Journal of International Business Studies, 8(1), 23-32. http://dx.doi.org/10.1057/palgrave.jibs.8490676

Johanson, J., \& Vahlne, J. E. (2009). The Uppsala Internationalization Process Model Revisited: From Liability of Foreignness to Liability of Outsidership. Journal of International Business Studies, 40, 1411-1431. http://dx.doi.org/10.1057/jibs.2009.24

Jovanovic, B., \& MacDonald, G. (1994). The Life Cycle of a Competitive Industry. Journal of Political Economy, 102(2), 322-347. http://dx.doi.org/10.1086/261934

Kessides, I. (1990). Towards a testable model of entry: A study of the U.S. manufactured industries. Economica, 57(226), 219-238. http://dx.doi.org/10.2307/2554161

Keupp, M. M., \& Gassmann, O. (2009). The Past and the Future of International Entrepreneurship: A Review and Suggestions for Developing the Field. Journal of Management, 35(3), 600-633. http://dx.doi.org/10.1177/0149206308330558

Khemani, R. S., \& Shapiro, D. M. (1986). The determinants of new plant entry in Canada. Applied Economics, 18(11), 1243-1257. http://dx.doi.org/10.1080/00036848600000077

Klepper, S. (1996). Entry, Exit, Growth and Innovation Over the Product Life Cycle. American Economic Review, $86(3), 562-583$

Klepper, S. (1997). Industry Life Cycles. Industrial and Corporate Change, 6(1), 145-181. http://dx.doi.org/10.1093/icc/6.1.145

Klepper, S. (2002). The capabilities of new firms and the evolution of the US automobile industry. Industrial and Corporate Change, 11(4), 645-666. http://dx.doi.org/10.1093/icc/11.4.645

Klepper, S., \& Graddy, E. (1990). The Evolution of New Industries and the Determinants of Market Structure. Rand Journal of Economics, 21(1), 27-44. http://dx.doi.org/10.2307/2555491

Klepper, S., \& Miller, J. (1995). Entry, Exit, and Shakeouts in the United States in New Manufactured Products. 
$\begin{array}{llll}\text { International Journal of Industrial } & \text { Organization, } & \text { 13(4), } & \text { 567-591. }\end{array}$ http://dx.doi.org/10.1016/0167-7187(95)00505-6

Klepper, S., \& Simons, K. L. (2000). Dominance by Birthright: Entry of Prior Radio Producers and Competitive Ramifications in the US Television Receiver Industry. Strategic Management Journal, 21, 997-1016. http://dx.doi.org/10.1002/1097-0266(200010/11)21:10/11<997::AID-SMJ134>3.0.CO;2-O

Knight, G. A., \& Cavusgil, S. T. (2004). Innovation, Organizational Capabilities, and the Born-Global Firm. Journal of International Business Studies, 35, 124-141. http://dx.doi.org/10.1057/palgrave.jibs.8400071

Kogut, B., \& Zander, U. (1992). Knowledge of the Firm, Combinative Capabilities and the Replication of Technology. Organization Science, 3(3), 383-397. http://dx.doi.org/10.1287/orsc.3.3.383

Landström, H., \& Lohrke, F. (2010). Historical Foundations of Entrepreneurship Research. Edward Elgar. http://dx.doi.org/10.4337/9781849806947

Lee, S. H., Peng, M. W., \& Barney, J. B. (2007). Bankruptcy Law and Entrepreneurship Development: A Real Options Perspective. Academy of Management Review, 32(1), 57-272.

Lin, J., \& Nabergoj, A. S. (2014). A Resource-based View of Entrepreneurial Creativity and Its Implications to Entrepreneurship Education. Economic and Business Review, 16(2), 163-183. Retrieved from http://www.ebrjournal.net/sites/index.php

Lippman, S. A., \& Rumelt, R. P. (1982). Uncertain Imitability: An Analysis of Interfirm Differences in Efficiency under Competition. The Bell Journal of Economics, 13(2), 418-438. http://dx.doi.org/10.2307/3003464

Malerba, F., \& Orsenigo, L. (1995). Schumpeterian patterns of innovation. Cambridge Journal of Economics, 19(1), 47-65.

Malerba, F., \& Orsenigo, L. (1996). Schumpeterian patterns of innovation are technology-specific. Research Policy, 25(3), 451-478. http://dx.doi.org/10.1016/0048-7333(95)00840-3

Malerba, F., Nelson, R. R., Orsenigo, L., \& Winter, S. G. (2008). Vertical integration and disintegration of computer firms: A History-friendly model of the co-evolution of the computer and semiconductor industries. Industrial and Corporate Change, 17(2), 197-231. http://dx.doi.org/10.1093/icc/dtn001

Mason, C., \& Harvey, C. (2013). Entrepreneurship: Contexts, Opportunities and Processes. Business History, 55(1), 1-8. http://dx.doi.org/10.1080/00076791.2012.687542

Mata, J. (1996). Markets, Entrepreneurs, and the Size of New Firms. Economic Letters, 52(1), 89-94. http://dx.doi.org/10.1016/0165-1765(96)00840-3

McDougall, P. P., \& Oviatt, B. M. (2000). International Entrepreneurship: The Intersection of Two Research Paths. Academy Management Journal, 43(5), 902-906. http://dx.doi.org/10.2307/1556418

McDougall, P. P., Oviatt, B. M., \& Shrader, R. C. (2003). A Comparison of International and Domestic Ventures. Journal of International Entrepreneurship, 1(1), 59-82. http://dx.doi.org/10.1023/A:1023246622972

Mejri, K., \& Umemoto, K. (2010). Small- and Medium-sized Enterprise Internationalization: Towards the Knowledge-based Model. Journal of International Entrepreneurship, 8(2), 156-167. http://dx.doi.org/10.1007/s10843-010-0058-6

Mezias, J. M., \& Mezias, S. J. (2000). Resource Partitioning, the Founding of Specialist Firms, and Innovation: The American Feature Film Industry, 1912-1929. Organization Science, 11(3), 306-322. http://dx.doi.org/10.1287/orsc.11.3.306.12504

Morrison, A. (2006). A contextualisation of entrepreneurship. International Journal of Entrepreneurial Behaviour \& Research, 12(4), 192-209. http://dx.doi.org/10.1108/13552550610679159

Nelson, R., \& Winter, S. (1982). An Evolutionary Theory of Economic Change. Cambridge, MA: Harvard University Press.

Orr, D. (1974). The determinants of entry: A study of the Canadian manufacturing industries. Review of Economics and Statistics, 56(1), 58-66. http://dx.doi.org/10.2307/1927527

Oviatt, B. M., \& McDougall, P. P. (1994). Towards a Theory of International New Ventures. Journal of International Business Studies, 25(1), 45-64. http://dx.doi.org/10.1057/palgrave.jibs.8490193

Oviatt, B. M., \& McDougall, P. P. (1995). Global Start-ups: Entrepreneurs on a Worldwide Stage. Academy of 
Management Executive, 9(2), 30-44. http://dx.doi.org/10.5465/ame.1995.9506273269

Oviatt, B. M., \& McDougall, P. P. (2005). Defining International Entrepreneurship and Modeling the Speed of Internationalization. Entrepreneurship Theory and Practice, 29(5), 537-553. http://dx.doi.org/10.1111/j.1540-6520.2005.00097.x

Péli, G., \& Nooteboom, B. (1999). Market Partitioning and the Geometry of the Resource Space. American Journal of Sociology, 104(4), 1132-53. http://dx.doi.org/10.1086/210138

Prasertsakul, D. (2013). The Role of Dynamic Capabilities in Export Performance of Firms from Emerging Economies. International Business Research, 6(8), 102-112. http://dx.doi.org/10.5539/ibr.v6n8p102

Schumpeter, J. (1934, first published 1911). The Theory of Economic Development. Cambridge Mass: Harvard University Press.

Schumpeter, J. (1950, first published 1942). Capitalism, Socialism and Democracy, Harper Brothers, New York. In M. Schwartz, (Ed.), The Nature and Scope of Contestability Theory (pp. 37-57). Oxford Economic Papers.

Shane, S., \& Venkataraman, S. (2000). The promise of entrepreneurship as a field of research. Academy of Management Review, 25(1), 217-221. http://dx.doi.org/10.5465/amr.2000.2791611

Shepherd, D. A. (2003). Learning from Business Failure: Propositions about the Grief Recovery Process for the Self-Employed. Academy of Management Review, 28(2), 318-328. http://dx.doi.org/10.5465/AMR.2003.9416377

Simon, H. (1982). Models of Bounded Rationality. Cambridge Mass: MIT Press.

Sommer, L. (2010). Internationalization Process of Small- and Medium-sized Enterprises-A Matter of Attitude? Journal of International Entrepreneurship, 8(3), 288-317. http://dx.doi.org/10.1007/s10843-010-0052-z

Short, J. (2009). The Art of Writing a Review Article. Journal of Management, 35(6), 1312-1317. http://dx.doi.org/10.1177/0149206309337489

Swaminathan, A. (1995). The Proliferation of Specialist Organizations in the American Wine Industry, 1941-1990. Administrative Science Quarterly, 40(4), 653-680. http://dx.doi.org/10.2307/2393757

Swedberg, R. (2000). Entrepreneurship: The Social Science View. Oxford University Press.

Teece, D. J., Pisano, G., \& Shuen, A. (1997). Dynamic capabilities and strategic management. Strategic Management Journal, $18(7), \quad 509-533$. http://dx.doi.org/10.1002/(SICI)1097-0266(199708)18:7<509::AID-SMJ882>3.0.CO;2-Z

Tushman, M., \& Anderson, P. (1986). Technological Discontinuities and Organizational Environments. Administrative Science Quarterly, 31(3), 439-465. http://dx.doi.org/10.2307/2392832

Ucbasaran, D., Westhead, P., \& Wright, M. (2009). The Extent and Nature of Opportunity Identification by Repeat Entrepreneurs. Journal of Business Venturing, 24(2), 99-115. http://dx.doi.org/10.1016/j.jbusvent.2008.01.008

Utterback, J., \& Abernathy, W. (1975). A Dynamic Model of Process and Product Innovation. Omega, 3(6), 639-656. http://dx.doi.org/10.1016/0305-0483(75)90068-7

Utterback, J., \& Suarez, F. (1993). Innovation, Competition, and Industry Structure. Research Policy, 22(1), 1-21. http://dx.doi.org/10.1016/0048-7333(93)90030-L

Vernon, R. (1966). International Investment and International Trade in the Product Cycle. The Quarterly Journal of Economics, 80(2), 190-207. http://dx.doi.org/10.2307/1880689

Windrum, P. (2003). Unlocking a lock-in: Towards a model of technological succession. In P. P. Saviotti (Ed.), Applied Evolutionary Economics: New Empirical Methods and Simulation Techniques. Edward Elgar. http://dx.doi.org/10.4337/9781781952894.00019

Windrum, P., \& Birchenhall, C. (2005). Structural change in the presence of network externalities: A co-evolutionary model of technological successions. Journal of Evolutionary Economics, 15(2), 123-148. http://dx.doi.org/10.1007/s00191-004-0226-8

Winter, S. (1984). Schumpeterian Competition in Alternative Technological Regimes. Journal of Economic Behaviour and Organisation, 5(3-4), 287-320. http://dx.doi.org/10.1016/0167-2681(84)90004-0

Winter, S. (2003). Understanding dynamic capabilities. Strategic Management Journal, 24(10), 991-995. 
http://dx.doi.org/10.1002/smj.318

Wright, M., Westhead, P., \& Ucbasaran, D. (2007). The Internationalization of SMEs and International Entrepreneurship: A Critique and Policy Implications. Regional Studies, 41(7), 1013-1030. http://dx.doi.org/10.1080/00343400601120288

Zaheer, S. (1995). Overcoming the Liability of Foreignness. Academy of Management Journal, 38(2), 341-363. http://dx.doi.org/10.2307/256683

Zahra, S. A., \& George, G. (2002). International entrepreneurship: The current status of the field and future research agenda. In M. Hitt, D. Ireland, D. Sexton, \& M. Camp (Eds.), Strategic entrepreneurship: Creating an integrated mindset (pp. 255-288). Blackwell Publishers.

Zahra, S. A., Ireland, R. D., \& Hitt, M. A. (2000). International expansion by new venture firms: International diversity, mode of market entry, technological learning, and performance. Academy of Management Journal, 43(5), 925-950. http://dx.doi.org/10.2307/1556420

Zahra, S. A., Korri, J. S., \& Yu, J. (2005). Cognition and international entrepreneurship: Implications for research on international opportunity recognition and exploitation. International Business Review, 14(2), 129-146. http://dx.doi.org/10.1016/j.ibusrev.2004.04.005

Zhang, J., \& Dai, X. (2013). Internationalization and "Go-Global" Strategies of Enterprises in Jiaxing City, Zhejiang Province, PRC. International Business Research, 6(5), 133-141. http://dx.doi.org/10.5539/ibr.v6n5p133

\section{Notes}

Note 1 . This is due to the fact that when the prior takes only two values, even a small number of trials (i.e. of entering firms) "[...] can move the posterior dramatically in one direction or another" (Horvath et al., 2001).

Note 2. For a detailed discussion of the hypotheses and of the geometric representation of the model, see Péli and Nooteboom (1999).

Note 3. For a detailed discussion of the differences between homogenous and heterogeneous resource bases, and the related organizations' possible strategies, see Carroll (1985).

Note 4. Carroll employs the example of readers who buy more than one newspaper.

Note 5. In one dimension a producer is represented as a segment; moving to 2 dimensions we have circles; in 3D we have spheres, and hyperspheres afterwards.

Note 6. Building a single formal model could be achievable in presence of such complex phenomena only by implementing simulation techniques, which is not the goal of this paper.

Note 7. For example, Götz (2002) presents a formal model in which a wide range of patterns of entry and market structures emerge. Considering a monopolistically competitive setting without uncertainty in a dynamic fashion, assuming the existence of sunk costs (entry barriers), a limited number of potential entrants and heterogeneity among firms, Götz shows the role of windows of profit opportunities in driving the evolution of the entry process. A rich series of cases come forward: the model is able to exhibit the product life cycle pattern, the product life cycle with the late stage entry, the traditional case in which only the most efficient firms enter the market deterring less efficient firms' entry and the path dependent case (in the sense that the equilibrium composition of types of firms is determined by the sequence of potential entrants).

Note 8. As happened in the case of photolithographic machines.

Note 9. Formally, we assume $\mathrm{H}(\mathrm{s})$ to be continuous for all $\mathrm{s}<\mathrm{s}_{\max }$ and $\mathrm{H}\left(\mathrm{s}_{\max }\right)=1$.

Note 10. We assume that $g^{\prime}\left(\mathrm{rd}_{\mathrm{it}}\right)>0$ and $\mathrm{g}^{\prime}\left(\mathrm{rd}_{\mathrm{it}}\right)<0$ for all $\mathrm{rd}_{\mathrm{it}}>0$, and $\mathrm{l}^{\prime}\left(\mathrm{rc}_{\mathrm{it}}\right)>0$ and $\mathrm{l}^{\prime}\left(\mathrm{rc}_{\mathrm{it}}\right)<0$ for all $\mathrm{rc}_{\mathrm{it}}>0$, indicating diminishing returns.

\section{Appendix A}

The Industry Life-Cycle Model (Klepper, 1996).

Formally, we indicate with $M_{t}$ the number of potential entrants at time $t$, each of which is characterized by a given level of innovative expertise $s_{i}$, that is known before the entry decision, where $i$ indicates the i-th firm. $H(s)$ indicates the cumulative distribution of innovative expertise, which is assumed to be the same for the potential 
entrants in each period. Assume, also, that in each period there is at least one potential entrant that is endowed with the maximum (Note 9) possible innovative expertise $s_{\max }$. Firms are assumed to be atomistic and price takers. In every period, firms produce the standard product $Q_{i t}$, and decide the amount to invest in product R\&D $r d_{i t}$, and process R\&D $r c_{i t}$, and also the level of output expansion $\Delta q_{i t}$, in order to maximize the current expected profits.

Each firm $i$ at time $t$ has a probability of succeeding in product innovation and thus selling a distinctive version of the standard product that is bought by new buyers and it ensures a one-period gross monopoly profit $G$ (after one period it is assumed that all product innovations are imitated and incorporated into the standard product) that is equal to $\left[s_{i}+g\left(r d_{i t}\right)\right]$. Moreover, investing in process $\mathrm{R} \& \mathrm{D}$, each firm has the possibility to lower its average production cost $c$ to $\left[c-l\left(r c_{i t}\right)\right]$. The functions $g\left(r d_{i t}\right)$ and $l\left(r c_{i t}\right)$ reflect the opportunities for product and process innovation respectively (Note 10).

The expected profits of firm $i$ at time $t$ are given by:

$$
\Pi_{i t}^{e}=\left[s_{i}+g\left(r d_{i t}\right)\right] \cdot G+\left\{Q_{i t-1}\left(\frac{Q_{t}}{Q_{t-1}}\right)+\Delta q_{i t}\right\} \cdot\left\{p_{t}-\left[c-l\left(r c_{i t}\right)\right]\right\}-r d_{i t}-r c_{i t}-m\left(\Delta q_{i t}\right)-F
$$

where:

- $Q_{t}=f_{t}\left(p_{t}\right)$ is the total market demand for the standard product at time $t$, such that $\left(Q_{t} / Q_{t-1}\right)$ is the growth in the total output of the standard product in the market from $t-1$ to $t$, and consequently $\left[Q_{i t-1}\left(Q_{t} / Q_{t-1}\right)\right]$ indicates the growth of firm $i$ 's sales of the standard product from $t-1$ to $t$;

- $\quad p_{t}$ is the price of the standard product at time $t$ and it is assumed to clear the market in every period;

- the function $m\left(\Delta q_{i t}\right)$ represents the cost of output expansion and it exhibits increasing marginal adjustment costs, such that the more a firm wants to increase its market share, the greater the cost at the margin it has to incur (for example, marketing costs to attract consumers);

- $\quad F$ is the fixed periodical cost that firms incur in order to monitor other firms' product innovations.

The focus of our analysis rests on the process of entry. The entry rule is specified as follows. Let $\Pi^{\mathrm{e}}{ }^{*}$ indicate the expected profits evaluated at the profit maximizing choices $r d_{i t}{ }^{*}, r c_{i t}{ }^{*}$, and $\Delta q_{i t}{ }^{*}$. Potential entrants, then, enter into the industry if $\Pi_{\text {it }}^{\mathrm{e}^{*}}>0$, are indifferent about entering if $\Pi_{\text {it }}^{\mathrm{e}^{*}=0}$ and stay out if $\Pi_{\text {it }}^{\mathrm{e}^{*}<0}$ ( incumbent firms stay if the expected profits are positive and exit the market otherwise). The number of entrants is specified as:

$$
E_{t}=M_{t}\left[1-H\left(s_{t}^{t}\right)\right]
$$

where $E_{t}$ indicates the number of newcomers and $s_{t}^{t}$ the minimum product innovation expertise among potential entrants at time $t$. It is demonstrated in the model that $r c_{i t}$, and $\Delta q_{i t}$ are smaller for later entrants, meaning that $\Pi_{\text {it }}^{\mathrm{e}}$ are lower for later entrants, given $s_{i}$. It follows that the minimum product innovation expertise $s_{t}^{t}$ needed to profitably enter increases over time. This means that eventually entry is unprofitable and it declines to zero. More precisely, the number of entrants $E_{t}$ falls over time unless $M_{t}$ rises sufficiently to offset the decrease of $\left[1-H\left(s_{t}^{t}\right)\right]$.

The intuition behind the rise in $M_{t}$ might be found in spin-offs and diversifying firms. The temporal pattern of the number of entrants, then, as predicted by the entry path 1 and entry path 2 in Figure 1, has to be examined in accordance with the specific industry considered: in those industries where spin-offs and diversifying entrants are important in the early phase of the industry, we would argue that the entry path 1 is more appropriate.

\section{Copyrights}

Copyright for this article is retained by the author(s), with first publication rights granted to the journal.

This is an open-access article distributed under the terms and conditions of the Creative Commons Attribution license (http://creativecommons.org/licenses/by/3.0/). 